\title{
COMMENTS
}

\section{PER CURIAM DECISIONS OF THE SUPREME COURT: 1957 TERM}

For approximately three decades after per curiam opinions were first published in the official United States Reports, ${ }^{1}$ it was generally assumed that only indisputably clear cases were disposed of by such decisions. ${ }^{2}$ Since doubt was cast on this assumption in 1930 by Professors Frankfurter and Landis ${ }^{3}$ there have been a few studies, for the most part critical, of selected phases of the Supreme Court's per curiam practice. ${ }^{4}$ However, no intensive survey of a full year's per curiams has ever been published. With the present study the editors of the Review attempt a step toward remedying this deficiency by initiating a series of annual studies of the Court's per curiam decisions. It is hoped the surveys will provide both a critique of the use of per curiams and speculation about the substantive law which may be hidden by the terseness of such opinions.

\section{I}

During the 1957 term the Court handed down 175 decisions labelled "per curiam." This raw total, however, is not a satisfactory figure for comparison and analysis because it contains a large number of decisions which were in no meaningful sense on the merits. Forty-six moot cases, orders in original jurisdiction cases, denials and dismissals of certiorari, and the like were disposed of in per curiams, leaving 129 cases decided on the merits..$^{5}$ This refined total is approximately the same as that for the preceding term but substantially greater than similarly computed figures for the terms five and ten years before. ${ }^{6}$ The

${ }^{1}$ The first per curiams were published in 1896. It has been suggested that for some years thereafter not all of the per curiam decisions of the Supreme Court were published. Supreme Court Per Curiam Practice: A Critique, 69 Harv. L. Rev. 707 n. 5 (1956).

${ }^{2}$ See e.g., Hughes, The Supreme Court of the United States 64 (1928).

${ }^{3}$ Frankfurter and Landis, The Business of the Supreme Court at October Term, 1929, 44 Harv. L. Rev. 1, 8, 10-12 (1930).

${ }^{4}$ See e.g., Brown, Foreword to the Supreme Court, 1957 Term, 72 Harv. L. Rev. 77 (1958); Bickel and Wellington, Legislative Purpose and the Judicial Process: the Lincoln Mills Case, 71 Harv. L. Rev. 1, 3 (1957); Sacks, Foreword to the Supreme Court, 1953 Term, 68 Harv. L. Rev. 96 (1954); Ulman \& Spears, "Dismissed for Want of a Substantial Federal Question," 20 B. U. L. Rev. 501 (1940); Supreme Court Per Curiam Practice: A Critique, 69 Harv. L. Rev. 707 (1956); The Insubstantial Federal Question, 62 Harv. L. Rev. 488 (1949).

${ }^{5}$ Although they have no precedent value, Hertz v. Wordman, 218 U.S. 205, 213 (1910), opinions by an equally divided court are included because the split on the Court may flag an area of possible development in the law.

${ }^{6}$ The refined totals for the 1956, 1952 and 1947 terms are 131, 56 and 25 per curiams, respectively. 
number of per curiam decisions on the merits in the 1957 term exceeded by roughly one-third the number of cases with full, signed opinions. ${ }^{7}$

Tables 1-7 depict various aspects of the term's per curiam practice. Since the formulation of conclusions from the tables would be almost wholly guesswork unless it could be reliably stated how many of the per curiam cases deserved fuller treatment, the tables are presented mainly as a convenient way of summarizing data. Two observations, though, are supported by the tables. First, the Court hears argument in only a small proportion of the cases. Second,

TABLE 1

\section{SUBJECT MATTER}

Principal Subject

Per

Curiams

First Amendment: Free Speech............... $\quad 5$

Immigration and Naturalization. . . . . . . . . . . . . . 6

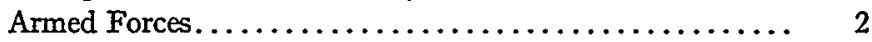

Patent and Copyright. ..................... 2

Federal Taxation ........................ 3

Investigative Powers of Federal Administrative Agencies. . 2

Federal Regulation under the Commerce Clause:

Antitrust........................... 3

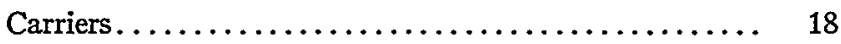

Communications........................ 2

Compensation and Employer Liability........... 7

Labor................................ 4

Unfair Competition. ..................... 2

Federal Agency Actions (not otherwise classified)....... 5

Federal Rules of Civil Procedure................ 3

Federal Criminal Cases:

Procedure........................... 18

Crimes............................... 2

Federal Habeas Corpus...................... 1

State Taxation......................... 3

State Regulation of Commerce................ 2

Fourteenth Amendment:

Criminal Procedure. . . . . . . . . . . . . . 7

Freedom of Speech...................... 3

State Statutes (not otherwise classified) . . . . . . 25

Other................................. 1

Statutes and Treaties (not otherwise classified):

Federal.......................... 1

State............................ 2

Total............................... 129

iThere were 109 full, signed opinions. Compare the ratio during the 1957 term with that for the 1956, 1952, and 1947 terms when there were, respectively, 99, 105, and 109 full, signed opinions. See note 6 supra for the refined total of per curiams during those years. 
TABLE 2

ORIGIN OF CASES

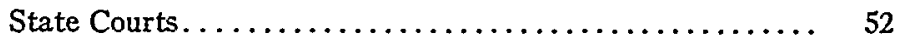

Lower Federal Courts..................... 76

Specialized Federal Courts..................... 1

TABLE 3

JURISDICTIONAL BASIS

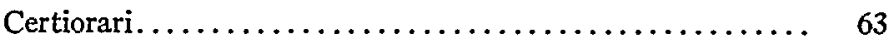

Appeal. ............................ 66

TABLE 4

ORAL ARGUMENT

With . . . . . . . . . . . . . . . . . . . . . . . 19

Without. ............................ 110

TABLE 5

Treatment of Cases

Orally

Argued Total

Without explanation or citation............. $2 \quad 68$

With citation only $\ldots \ldots \ldots \ldots \ldots \ldots \ldots \ldots \ldots \ldots, 6 \ldots \ldots \ldots \ldots$

With explanation.................. $11 \quad 27$

TABLE 6

DISPOSITION OF CASES

Appeal Dismissed for Want of Substantial Federal Question 31

Appeal Dismissed...................... 7

Judgment Affirmed by an Equally Divided Court........ 3

Judgment Affirmed............................. 29

Judgment Vacated and Case Remanded for Reconsideration

in Light of Authority Cited . .................. 11

Judgment Vacated and Case Remanded with Instructions

Other than To Reconsider in Light of Authority Cited... . 5

Judgment Reversed $\ldots \ldots \ldots \ldots \ldots \ldots \ldots \ldots \ldots \ldots \ldots \ldots, \quad 31$

Judgment Reversed on Confession of Error........... 9

Miscellaneous............................. 4 
the Court only infrequently includes an explanation for its decision. Even some of the cases listed in Table 5 as including an explanation contain barely more than dogmatic statements of conclusions. ${ }^{8}$ There appears to be a high correlation between the granting of oral argument and the use of an explanatory opinion. This suggests that in those cases in which the Court has presumably recognized the desirability of more enlightenment than the briefs could provide, there is a concomitant awareness of the need for more than a one-sente ce opinion. The converse of this observation, however, seems to merit examination; it may be asked whether per curiam treatment means the proper result of a case is so clear that elaboration is superfluous.

The negative answer given by several commentators ${ }^{9}$ is supported by the

TABLE 7

MINORITY VOTES OF INDIVIDUAL JUSTICES

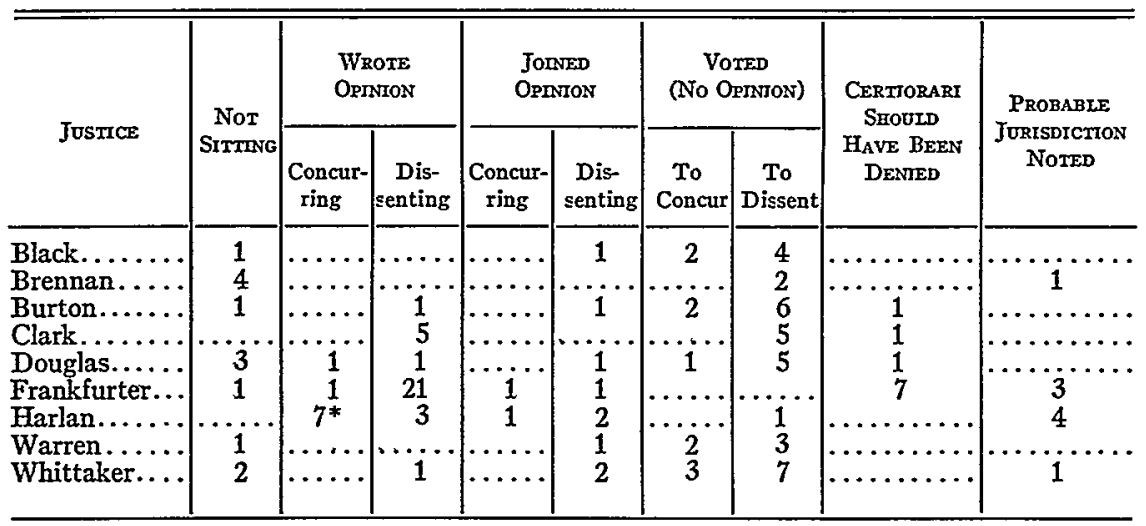

* Two of the seven express Justice Harlan's opinion that certiorari should not have been granted but since the Court has taken the case he thinks it necessary to decide it on the merits.

detailed examination made below in Part $\Pi$ of some of the cases in which the wisdom of summary treatment seems questionable. The cases examined are by no means typical. Brief disposition appears clearly proper for many and reasonably justifiable for nearly all of the term's per curiams. Nevertheless, it may be suggested that the Court seemingly is misusing the per curiam opinion in at least three ways: (1) In some instances the Court appears to use per curiams to avoid an expression of opinion on important issues. (2) Frequently the Court does not make clear what is decided. (3) At times the law appears to be altered with little if any expressed explanation or justification.

MaCrary v. Aladdin Radio Industries, Inc. ${ }^{10}$ perhaps the per curiam of the term in which summary treatment is least justifiable, falls into the first category. By vacating and remanding that case for reconsideration the Court with

${ }^{8} \mathrm{Cf}$. Bickel and Wellington, op. cit. supra note 4 , at 3.

${ }^{9} \mathrm{See}$ authorities cited in note 4 supra.

10355 U.S. 8 (1957), discussed following note 53 infra. 
seemingly little reason for doing so passed by an opportunity to resolve four serious questions which have been plaguing the labor law field. Important questions regarding the borderline between free speeh and obscenity apparently were avoided in four censorship cases." Several of the cases dismissed per curiam for want of a substantial federal question appear to have presented novel constitutional issues. ${ }^{12}$

In several of the cases discussed in Part II it is difficult to determine what the Court held. In some instances the Court cited authority which is not obviously controlling and in some instances not even persuasive. For example, the Court remanded Joines $v$. United States ${ }^{13}$ to the court of appeals for reconsideration in light of Jones v. United States, ${ }^{14}$ a case with a full opinion handed down the same day. As the court of appeals on remand pointed out, Joines was precisely the case which Jones had expressly distinguished; the court understandably declined to modify its earlier decision. In some of the dismissals for lack of a substantial federal question it is difficult to ascertain whether the Court is in fact passing on the substantiality of the federal question or deciding only that a decision of that question is not demanded by the case presented. In cases such as the two per curiams delimiting the FTC's power over the insurance business, ${ }^{15}$ the Court's inarticulateness makes it difficult to reconcile apparently inconsistent decisions.

Some of the per curiams appear to make, without expressed justification, substantial alterations of prior law. For example, the oft-cited case of Mooney v. Holohan ${ }^{16}$ was used to dispose of Alcorta $v$. Texas, ${ }^{17}$ the facts of which differ substantially from those of any prior decision applying the Mooney doctrine. In Eskridge v. Washington Prison Board ${ }^{18}$ the Court appears to have silently answered several important questions left open by Griffin v. Illinois. ${ }^{19}$

The procedural unfairness which inheres in the summary consideration usually given cases decided per curiam has attracted suggestions for change. ${ }^{20}$ The three categories of apparent misuse equally invite reform. Cases in the first category seemingly serve no useful function. It is to be expected that the Court will find that some cases in which certiorari has been granted can be decided only by passing on issues considered not yet appropriate for decision.

11356 U.S. 25 (1958), discussed following note 176 infra.

${ }^{12}$ See e.g., Strauss v. University of New York, 355 U.S. 394 (1958), discussed following note 233 infra.

13357 U.S. 493 (1958), discussed following note 316 infra.

14357 U.S. 573 (1958).

${ }^{15}$ FTC v. Crafts, 355 U.S. 9 (1957), and FTC v. National Casualty Co., 357 U.S. 560 (1958), discussed following note 140 infra.

${ }^{16} 294$ U.S. 103 (1934).

${ }^{17} 355$ U.S. 28 (1957), discussed following note 252 infra.

${ }^{18} 355$ U.S. 947 (1958), discussed following note 274 infra.

19351 U.S. 12 (1956).

${ }^{20}$ See particularly Brown, op. cit. supra note 4; Harv. L. Rev., op. cit. supra note 1. 
In such cases it appears preferable to dismiss certiorari as improvidently granted rather than vacating and remanding for reconsideration or otherwise disposing of the cases on the merits. If a case presenting novel issues of substance is on appeal, the mandatory nature of the Court's jurisdiction seems to require that there should be a decision with a thorough discussion of all the issues. It is contrary to Congress' intention to convert the dismissal for want of a substantial federal question into a discretionary device comparable to the denial of certiorari. ${ }^{21}$

Reforms inspired by the cases in which the Court's holding is unclear must be designed to eliminate the disadvantages which such opinions have. Although probably no decision has ever been free from ambiguity, per curiams are peculiarly susceptible to misinterpretation. The facts thought relevant by the Court are rarely stated. Few attorneys and judges have access to the briefs to determine what issues were presented for decision. When the Court reverses a decision, if multiple errors were alleged even access to the briefs does not make it possible to determine exactly which assignments of error the Court found meritorious. In drawing inferences about the meaning of per curiam decisions it is frequently necessary to assume all the Justices in the majority thought alike. However, many summary opinions may be the net result of different approaches among the various Justices. These considerations, coupled with the lack of argument and in many cases of briefs on the merits, ${ }^{22}$ should preclude surprise at the fact that per curiams are at times ignored by lower courts and indeed by the Supreme Court itself. ${ }^{23}$ Appropriate reforms should include statements of facts considered relevant and issues decided, citation to specific portions of authorities thought controlling, and explanations why those authorities are thought to govern. When, as in the cases in the third category, the law is being altered, a full statement of the change and the reasons therefore seem essential. If these reforms unduly burden the Court it may be suggested that the ultimate solution lies in decreasing the number of cases taken for consideration.

II

\section{A. Hot Cargo and Pre-emption}

The four labor cases decided per curiam during the 1957 Term strikingly illustrate both the proper and the questionable uses of summary disposition. One case was on all fours with precedent and two others clarified the scope of existing law. The wisdom of summary treatment in the remaining case, however, is highly doubtful.

21 See Frank, The United States Supreme Court: 1950-51, 19 U. of Chi. L. Rev. 165, 231 (1952).

${ }^{22}$ See Brown, op. cit. supra note 4.

${ }^{23}$ Per curiam decisions on the merits supposedly have precedential weight. They have been cited as authority by lower federal courts, state courts and by the Supreme Court itself. See e.g., Avondale Marine Ways, Inc. v. Henderson, 346 U.S. 366 (1953); Krausse v. United States, 194 F.2d 440 (C.A.2d, 1952); Bruestle v. Rich, 159 Ohio St. 13, 110 N.E.2d 778 (1953). However, at times per curiams directly in point seem not to be taken into account. See Harv. L. Rev., op. cit. supra note 1 , at 723 . 
$N L R B$ v. Milk Drivers Union ${ }^{24}$ represents a perfect use of the per curiam opinion. Following its own case of Rabouin v. NLRB, ${ }^{25}$ the Second Circuit Court of Appeals had held ${ }^{26}$ that $\$ 8(\mathrm{~b})(4)(\mathrm{A})$ of the National Labor Relations Act ${ }^{27}$ was not violated when a union involved in a labor dispute with a primary employer appealed to the employees of a secondary employer not to handle "unfair" goods, in accordance with a hot-cargo clause in the collective bargaining agreement to which the secondary employer was a party. The Second Circuit took the position that there could be no violation of $\$ 8(\mathrm{~b})(4)(\mathrm{A})$ without union encouragement of employees to coerce the secondary employer and that there was no coercion if employees were encouraged only to exercise a valid contractual right. ${ }^{28}$ In Carpenters Union v. $N L R B,{ }^{29}$ however, the Supreme Court decided that such an appeal by a union was an unfair labor practice in the absence of voluntary and ad hoc acquiescence by the employer. Silence on the part of the secondary employer was held not to constitute such acquiescence. Invoking the Carpenter decision the Supreme Court reversed the Second Circuit judgment in the Milk Drivers case. ${ }^{30}$

In Teamsters Union $\%$. Newell, ${ }^{31}$ a state court injunction against union picketing $^{32}$ was struck down on the authority of Thornhill $v$. Alabama. ${ }^{33}$ The three drivers employed by a small dairy had established a picket line to force the owner to reinstate one of them and to recognize the Teamsters as their bargaining representative. The pickets had taken pictures of customers patronizing the dairy and of non-union drivers working as replacements. ${ }^{34}$ Pointing out that the public had become generally apprehensive of being identified with a labor dispute, particularly so in the highly unionized community involved, the Kansas Supreme Court had held that the taking of pictures constituted intimidation and threatened use of force against the dairy's patrons and non-union

24 357 U.S. 345 (1958).

25195 F.2d 906 (C.A.2d, 1952).

${ }^{26}$ Milk Drivers Union v. NLRB, 245 F.2d 817 (C.A.2d, 1957).

${ }^{27} 49$ Stat. 452 (1935), as amended, 29 U.S.C.A. $\$ 158(d)(4)(A)$ (1952).

${ }^{28}$ After the Rabouin decision, the Courts of Appeals for the Ninth Circuit, NLRB v. United Brotherhood of Carpenters, 241 F.2d 147 (C.A.9th, 1957), and the District of Columbia Circuit, General Drivers Union v. NLRB, 247 F.2d 71 (App.D.C., 1957), had disagreed concerning the enforceability of hot-cargo clauses, with the District of Columbia supporting the position of the Second Circuit.

29357 U.S. 93 (1958).

${ }^{30}$ Carpenters Union is so closely on point that had it been handed down prior to the lower court consideration of Milk Drivers Union, there is no doubt that the Second Circuit would have overruled the Rabouin case.

31356 U.S. 341 (1958).

${ }^{32}$ Newell v. Teamsters Union, 181 Kan. 898, 317 P.2d 817 (1957).

${ }^{33} 310$ U.S. 88 (1940).

34 Although the Kansas court also mentioned that (1) profanity was used on the picket line, and (2) the police had received one telephone call alleging a disturbance, it is clear from the court's opinion that the finding of non-peaceful picketing did not rest upon these factors. 
employees.$^{35}$ Concluding that the atmosphere of intimidation generated by past conduct would survive even though future picketing might be peaceful, the court had upheld an injunction against all picketing ${ }^{36}$ on the authority of Milk Wagon Drivers Union v. Meadowmoor Dairies, Inc. ${ }^{37}$

The Supreme Court in Thornhill had characterized picketing as a means of publicizing a labor dispute and had accorded it protection as free speech under the First and Fourteenth Amendments. Although this broad holding had been limited in later decisions, ${ }^{38}$ its language was still applicable to the situation in Newell ${ }^{39}$ Taking pictures evidences more of a desire to publicize than to intimidate and threaten; indeed, publicity seems to have been characterized as per se intimidation by the Kansas court. The naked cite of Thornhill in the per curiam reversal appears to be an admonition to the state court that it must produce more evidence of intimidation than was found in the Newell case to justify a blanket injunction against picketing. ${ }^{40}$

35 "The possibility that a person's photograph might later be used to identify him as a person unfriendly to organized labor, and therefore subject him to possible physical violence, was a threat as real and present as if the picket had threatened him with violence if he dared to cross the picket line." 181 Kan. 898, 912, 317 P.2d 817, 829 (1957).

${ }^{36}$ In addition to specific injunctions against intimidation of employees or patrons through the use of photography and the broad injunction against picketing, the Kansas decree also covered all acts designed to boycott the dairy's business. Certainly the most significant result of 'he union's activities against the dairy was the almost unanimous consent of wholesale and retail outlets to a boycott of the dairy's products. This boycott was accomplished by union threats to stop delivery on all other items handled by these wholesalers and retailers. The basis for enjoining these activities is not clear. The Kansas opinion cites no authority and only in the syllabus prepared by the court is there a reference to Kan. Gen. Stat. \$44-809a(1) (Supp., 1955). This section contains provisions similar to those found in $\$ 8(b)(4)(A)$ of the National Labor Relations Act and would hardly seem to cover a situation in which the union had contacted only other employers and not the employees of these employers. Assuming, however, that Kansas does have some public policy barring these activities, such a policy would seem a proper basis for state action and presumably the per curiam reversal would not preclude the re-establishment of that portion of the Kansas decree dealing with the boycott. Cf., e.g., Giboney v. Empire Storage \& Ice Co., 336 U.S. 490 (1949); Allen Bradley Co. v. Local Union No. 3, 325 U.S. 797 (1945).

\section{U.S. 287 (1940).}

${ }^{33}$ For the historical development of the present judicial position that picketing, even when peaceful, is something more than free speech, see Teamsters Union v. Vogt, Inc., 354 U.S. 284 (1957). Since the objective of the picketing in Newell was not in conflict with any of the state policies which the Court has permitted to override the free-speech aspects of picketing but, instead, was an objective long recognized as lawful, it is clear that only the presence of unlawful means could have made the Thornhill holding inapplicable.

${ }^{39}$ " But no clear and present danger of destruction of life and property, or invasion of the right of privacy, or breach of the peace can be thought to be inherent in the activities of every person who approaches the premise of an employer and publicizes the facts of a labor dispute involving the latter." Thornhill v. Alabama, 310 U.S. 88, 105 (1940).

${ }^{40}$ Even if the Court had agreed that the photographic endeavors of the pickets constituted enjoinable coercion, it is unlikely that it would also have considered the atmosphere of threat and intimidation to be so inseparably bound up with peaceful picketing as to justify the sort of blanket injunction upheld in Meadowmoor. Instead, the Court would probably have required the coercive elements to be carefully separated from the peaceful picketing as in Youngdahl v. Rainfair, Inc., 355 U.S. 131 (1957). 
In the third per curiam case, District Lodge 34 v. Cavett Co., , $^{\text {th }}$ the Supreme Court reversed the Ohio Supreme Court ${ }^{42}$ on the authority of Amalgamated Meat Cutters v. Fairlawn Meats, Inc. ${ }^{43}$ Weber v. Anheuser-Busch, Inc., ${ }^{44}$ and Garner v. Teamsters Union. ${ }^{45}$ The union had picketed for recognition after losing an NLRB election; it was the only union involved. In enjoining the picketing, the Ohio court had held that there could be no pre-emption where the NLRB had already resolved the only existing labor dispute and one party simply rejected the result of the Board adjudication.

All three of the cases cited by the Court were concerned with state injunctions against union picketing, as in Cavelt, though only Weber also involved the element of a contemporaneous ${ }^{46}$ Board proceeding. In Weber, the employer's petition to the state court alleged, inter alia, that the union picketing ${ }^{47}$ violated $\S \S 8(\mathrm{~b})(4)(\mathrm{A}),(B)$, and (D) of the National Labor Relations Act. ${ }^{48}$ The Board ruling had considered only the violation of $\$ 8(\mathrm{~b})(4)(\mathrm{D})$ and had found that that section had not been violated. ${ }^{99}$ The Supreme Court emphasized that this finding would in no way have precluded the Board, had the charges been brought before it, from finding violations of $\$ \S 8(\mathrm{~b})(4)(\mathrm{A})$ and $(\mathrm{B})$. Furthermore, the picketing activity was such that if not prohibited by the Act, it could reasonably be deemed to be protected by the Act. In Garner, a minority union had picketed for organizational purposes, and, in Fairlawn, a minority union had picketed for recognition. In both cases the Court indicated that the Act had "taken hold" of such controversies under $\$ 8(\mathrm{~b})(2) . .^{50}$ In none of the three cases did the Court determine that the activity involved was, in fact, an unfair labor practice, ${ }^{51}$ nor has it yet had occasion to pass upon the status of minority picketing in the Cavett context. ${ }^{52}$ Its per curiam opinion in Cavelt, however,

4t 355 U.S. 39 (1957).

42166 Ohio St. 508, 143 N.E.2d 840 (1957), dismissing an appeal from 103 Ohio App. 45, 136 N.E.2d 276 (1956).

43353 U.S. 20 (1957).

44348 U.S. 468 (1955). 45346 U.S. 485 (1953).

${ }^{46}$ The initial complaint against the picketing was filed with the Board, but the employer commenced his state action months before the Board completed its deliberations. Weber v. Anheuser-Busch, Inc., 348 U.S. 468, 470-71 (1955).

${ }^{47}$ The union picketing was not for the purpose of recognition in the Cavett context but, instead, grew out of a long-standing jurisdictional dispute.

1849 Stat. 452 (1935), as amended, 29 U.S.C.A. $\$ 158$ (b)(4)(A), (B), (D) (1952).

19 District No. 9, International Ass'n of Machinists, 101 N.L.R.B. 346 (1952).

so 49 Stat. 452 (1935), as amended, 29 U.S.C.A. \$158(b)(2) (1952).

51 To the contrary, it expressly refrained from making any such determination, on the ground that that was within the province of the Board. Instead, the Court simply pointed out that the Act had already provided a remedy for the wrongs alleged in the various petitions. Garner v. Teamsters Union, 346 U.S. 485, 489 (1953); Weber v. Anheuser-Busch, Inc., 348 U.S. 468, 478 (1955); Amalgamated Meat Cutters v. Fairlawn Meats, Inc., 353 U.S. 20, 24 (1957); For a discussion of the possible implications of the Court's reference to Board remedies consult note 70 infra.

${ }^{52}$ The NLRB did decide in Curtis Brothers, Inc., 119 N.L.R.B. 232 (1957), that such picketing was a violation of $\$ 8(\mathrm{~b})(1)$ (A), but this determination was denied enforcement in Drivers Local 639 v. NLRB, 43 L.R.R.M. 2156 (App.D.C., 1958). Petition for writ of certiorari was filed in the Supreme Court Feb. 20, 1959, 27 U. S. L. Week 3251 (1959). 
indicates the foreclosure of state authority to enjoin peaceful minority picketing, irrespective of whether the picketing is for the purposes of organization or recognition and irrespective of whether the picketing is preceded by a Board election.

Probably the most questionable use of a per curiam during the entire 1957 term is McCrary v. Aladdin Radio Industries, Inc. ${ }^{53}$ in which the Supreme Court vacated the affirmance of a contempt conviction by a Tennessee Court of Appeals ${ }^{54}$ and remanded the case for consideration in the light of Teamsters Union v. Kerrigan Iron Works. ${ }^{55}$ The Kerrigan case in turn was a per curiam opinion of the previous term which, on the authority of Weber v. AnheuserBusch, Inc..$^{56}$ and General Drivers v. American Tobacco Co. ${ }^{57}$ reversed the affirmance of a permanent injunction by the same Tennessee Court of Appeals. ${ }^{58}$ American Tobacco was still another per curiam reversing the affirmance of a permanent injunction by the Kentucky Court of Appeals ${ }^{59}$ on the authority of the Weber case and Amalgamated Association v. Wisconsin Employment Relations Board ${ }^{60}$ (the Bus Employees case).

Aladdin Industries, Inc., (Industries) and Aladdin Radio Industries, Inc., (Radio) a subsidiary, carried on business under the same roof but with the employees of each represented by different unions (Locals 4802 and 5003, United Steelworkers, respectively). Industries, which filed the principal suit, depended upon fourteen motor carriers ${ }^{61}$ for transportation of its raw material and finished product. The contract between Local 5003 and Radio terminated, and the latter's employees struck and established a picket line which initially was ignored by both Industries' and the carriers' employees. Two weeks later, however, the truck drivers decided to honor the picket line, and the carriers not only stopped giving service but refused even to let Industries pick up goods at the carriers' terminals.

Preliminary injunctions running against the carriers and their employees were issued by a Tennessee state court and service was resumed for three months. When a second stoppage occurred, Industries filed several petitions in the state court against the carriers, the truck drivers, the president of Local 327, Teamsters Union (which represented the drivers), and the Local itself, alleging, among other things, a conspiracy between Local 327 and its officials to violate the injunction and to induce violations by the truck drivers. Finally,

${ }^{53} 355$ U.S. 8 (1957). This opinion also vacated a companion contempt case, Bratton v. Aladdin Industries, Inc.

${ }^{54}$ Aladdin Industries, Inc. v. Associated Transport, Inc., 298 S.W. $2 d 770$ (Tenn.App., 1956). The companion case of Aladdin Radio Industries, Inc. v. Adkins Transfer Co. was decided the same day in an unreported opinion.

${ }_{55} 353$ U.S. 968 (1957). $\quad \quad \quad 56348$ U.S. 468 (1955). $\quad{ }^{57} 348$ U.S. 978 (1955).

${ }^{58}$ Kerrigan Iron Works v. Cook Truck Lines, 296 S.W.2d 379 (Tenn.App., 1956).

${ }^{59} 264$ S.W.2d 250 (Ky., 1954).

60340 U.S. 383 (1951).

61 These carriers had a collective bargaining agreement with Local 327, Teamsters Union, covering their drivers, which provided that it was no violation of the contract for the carrier employees to refuse to cross the picket line of another union or to refuse to handle "unfair" goods. 
Local 327 also started to picket Industries, ostensibly for the purpose of organizing Industries' office employees. After hearngs the Chancellor found that the carriers had done their best to comply with the injunction, and the petitions as to them were dismissed. Criminal contempt convictions were then entered against certain individual drivers, Local 327 and its president. ${ }^{62}$

Similar situations gave rise to the injunctions involved in Kerrigan and American Tobacco. The history of Aladdin is, however, different from that of its per curiam predecessors in five respects. (1) The petitioners before the Supreme Court in Aladdin had been convicted of contempt for violating the injunction (the petitioners in Kerrigan and American Tobacco questioned only the injunction itself). (2) The injunction underlying the contempt citation was a preliminary one ${ }^{63}$ (the injunctions in Kerrigan and American Tobacco were permanent). (3) The injunction ran only against the carriers and their employees (the Kerrigan injunction ran against the carriers and the local union representing the carriers' drivers, and the American Tobacco injunction ran only against the drivers' local). (4) The injunction did not require members of the drivers' local union to cross a picket line established by other members of the same local (the American Tobacco injunction did, in effect, require union members to cross their own picket line). ${ }^{64}$ (5) The original petition did not allege unfair labor practices (such allegations were found in the Kerrigan and American Tobacco petitions). ${ }^{65}$

In the Aladdin situation the state is battling not one but two pre-emption spectres, one represented by the national labor policy and the other by the national transportation policy. The analysis of these federal-state problems involves four propositions which warranted elucidation by the Court. (1) There is no labor pre-emption in Aladdin because the conduct against which the injunction is directed is neither protected nor prohibited by the National Labor

62 It should be emphasized that neither the union nor its president were named in the injunctions. These parties were found guilty of contempt for wilful interference with the lawful processes of the court in establishing the Local 327 picket at Aladdin's premises following the issuance of the injunction. Aladdin Industries, Inc. v. Associated Transport, Inc., 298 S.W.2d 770, 784 (Tenn.App., 1956). For further discussion of the contempt activity consult note 89 infra. Similar interference by unorganized private persons would unquestionably have furmished a proper foundation for contempt citations. Cf. United Construction Workers v. Laburnum Construction Corp., 347 U.S. 656, 669 (1954).

${ }^{63}$ In Montgomery Building \& Construction Trades Council v. Ledbetter Erection Co., 344 U.S. 178 (1952), the Supreme Court held that the affirmance of a temporary injunction by the highest court of a state was not such a final judgment or decree as met the requirement in 28 U.S.C.A. $\$ 1257$ (1952), upon which Court review was conditional.

64 That is, the same local union represented both the carrier employees and the striking employees of American Tobacco's subsidiary.

65 These important differences plainly indicated that it would be an unnecessary, timeconsuming tactic to remand Aladdin to the same court which had been reversed in Kerrigan. Although the latter opinion had been handed down by the Court subsequent to the Tennessee decision in Aladdin, the distinctions had been pointed up in the briefs before the Supreme Court, and the Tennessee court had already discussed them with respect to American Tobacco. Certainly it could not be expected that the Tennessee court, which had studiously avoided any reference to its own Kerrigan decision, would have any trouble in distinguishing that case as well when the need arose. 
Relations Act. (2) Even if there are federal labor matters involved which would otherwise pre-empt state jurisdiction, they are only ancillary to a paramount concern for enforcement of the duties of common carriers. (3) This superior concern is properly enforceable by the state; there is no pre-emption by the Interstate Commerce Commission. (4) Even if it were decided that jurisdiction over the underlying dispute has been pre-empted by the requirements of national labor or national transportation policy, the contempt citation for violation of the state injunction should nevertheless be upheld since the injunction should at worst be classed as "void but non-frivolous."

Consider first the labor aspects of the Aladdin injunction requiring the carriers' employees to cross the picket line around the Industries and Radio plant. Whether considered from the shippers' point of view or the carriers' point of view, this injunction certainly touched upon employee activities in an industry affecting interstate commerce, some aspects of which the National Labor Relations Act was unquestionably intended to govern and to govern without state interference. Yet the Act has not been held to deprive the states of all jurisdiction over such employee activities. The instances to date where the Supreme Court has dropped the blanket of pre-emption have been situations where the activity involved could be said to be either protected or prohibited under the Act. In no case has the Court found pre-emption of jurisdiction over activity determined to be neither protected nor prohibited. Instead, it held in $U A W v$. Wisconsin Employment Relations Board ${ }^{66}$ (the Briggs-Stratton case) that such activity was a proper subject of state regulation. ${ }^{67}$

While the Court subsequently, in Garner v. Teamsters Union, ${ }^{68}$ employed language which might be interpreted as indicating that activity not found to be prohibited would be assumed to be protected, ${ }^{69}$ the same opinion referred to the Briggs-Stratton situation as one in which state power was not excluded. Moreover, in the Weber case the Court interpreted its Garner decision as resting upon the presence of prohibited activity, ${ }^{70}$ and, in describing situations subject

${ }^{86} 336$ U.S. 245 (1949).

${ }^{67}$ The Court upheld the state board's enjoining of recurrent, unannounced work stoppages, pointing out that there could be no possible conflict with the jurisdiction of the NLRB since the latter had no authority "either to investigate, approve or disapprove the union conduct in question. This conduct is governable by the State or it is entirely ungoverned." Id., at 254. ${ }_{68} 346$ U.S. 485 (1953).

60 "The detailed prescription of a procedure for restraint of specified types of picketing would seem to imply that other picketing is to be free of other methods and sources of restraint. For the policy of the National Labor Management Relations Act is not to condemn all picketing but only that ascertained by its prescribed processes to fall within its prohibitions. Otherwise, it is implicit in the Act that the public interest is served by freedom of labor to use the weapon of picketing. For a state to impinge on the area of labor combat designed to be free is quite as much an obstruction of federal policy as if the state were to declare picketing free for purposes or by methods which the federal Act prohibits." Id., at 499.

${ }^{70}$ This was certainly not an obvious interpretation of Garner. See Flays, State Courts and Federal Preemption, 23 Mo. L. Rev. 373, 374 (1958). The Court in Garner had not determined that the activity there involved was an unfair labor practice; the Court had merely held that the Pennsylvania statute in question was designed to regulate activity which was also regulated by the Board under the National Labor Relations Act. Garner v. Teamsters 
to state power, reaffirmed the applicability of Briggs-Stratton to injunctions of conduct neither prohibited nor protected by the Act. At the same time, the Court made it clear that the balance was going to be tipped toward finding activity either protected or prohibited. ${ }^{71}$ Nevertheless, in situations where employee activity cannot reasonably be held to be either protected or prohibited, state courts should still be permitted to exercise jurisdiction.

It must be conceded that considerable doubt is cast on the validity of this conclusion by certain other propositions presented in Garner and Weber. In addition to categorizing labor activities as protected, prohibited or neither, Garner held that it was for the Board, and not the courts, to decide into which category any particular activity fell..$^{72}$ Yet the Briggs-Stratton case, cited in Garner, had held that a state court was empowered to make this determination. In $W e b e r$ there was a reaffirmation of the proposition that the initial determination must be made by the Board, ${ }^{73}$ but the Court again approved of BriggsStratton and went on to say that "it is not easy for a state court to decide, merely on the basis of a complaint and answer, whether the subject matter is the concern exclusively of the federal Board and withdrawn from the State." It has been argued that the only proper conclusion from this confused state of affairs is that the whole field of labor activity has been pre-empted, and that Briggs-Stratton would not today be extended beyond its exact facts. ${ }^{75}$ Yet the Court has never repudiated its Briggs-Stratton holding and in its most recent pre-emption per curiam has, arguably, acknowledged the continued existence of the unpre-empted zone of activity neither protected nor prohibited. ${ }^{76} \mathrm{This}$ confusion must eventually be resolved by the Court, but until it has chosen to do so in clear and unmistakable terms, an argument can still be made in favor of

Union, 346 U.S. 485, 488-89 (1953). Nevertheless, the Court's discussion of possible Board remedies under the Act would seem to imply that an unfair labor practice was involved; it is difficult to conceive of a remedy without a corresponding violation.

71 "[W] here the moving party itself alleges unfair labor practices, where the facts reasonably bring the controversy within the sections prohibiting these practices, and where the conduct, if not prohibited by the federal Act, may be reasonably deemed to come within the protection afforded by that Act, the state court must decline jurisdiction ...." Weber v. AnheuserBusch, Inc., 348 U.S. 468, 481 (1955).

72 Garner v. Teamsters Union, 346 U.S. 485, 490 (1953).

${ }^{73}$ Weber v. Anheuser-Busch, Inc., 348 U.S. 468, 478 (1955).

${ }^{74} \mathrm{Id}$. at 481.

${ }^{75}$ Hays, State Courts and Federal Preemption, 23 Mo. L. Rev. 373, 376 (1958). The extent to which the state courts have reflected the confusion created by Garner and Weber is well documented in this article.

76 "The Florida courts were without jurisdiction to enjoin this organizational picketing, whether it was activity protected by $\$ 7$ of the National Labor Relations Act . . . or prohibited by $\$ 8(b)(4)$ of the Act. . . " Hotel Employees Union v. Sax Enterprises, Inc., 358 U.S. 270 271 (1959). It can also be argued that the above statement, an ungrammatical one as it stands, must be read with "whether or not" substituted for "whether," which would preclude the existence of an unpre-empted category. If such a reading was intended, it is submitted that the Court chose a most unsatisfactory manner of drawing to a close a five-year period of judicial confusion. 
the unpre-empted category. It will now be considered whether the employee activities leading up to the Aladdin injunctions can reasonably be said to fall into this category.

The one element which will always trigger a pre-emptive reaction on the part of the Court - the allegation of prohibited union activity-was certainly not present in the Aladdin case. In contrast to the tactics employed in Kerrigan and American Tobacco, the Industries and Radio petitions sought to enjoin neither the striking Radio employees or Local 5003, nor Local 327 or the members of the latter as such. Instead, the petitions sought injunctions running only against the carriers and their employees, ${ }^{77}$ based upon the failure of the latter to fulfill their common law and statutory duties, without referring in any way to concerted activity on the part of any group of employees. ${ }^{78}$

Nor can it be said that any employee activity prior to the issuance of the injunctions might reasonably fall under the ban of $\S 8(\mathrm{~b})$. There was no employer-employee dispute between Aladdin (referring collectively to Radio and Industries) and Local 327, the only union directly affected by the injunctions. The only possible unfair labor practice charge would seem to be in the context of a secondary boycott under $\$ 8(b)(4)(A) .{ }^{79}$ Such a charge could be successfully presented before the National Labor Relations Board only if it could be shown that some labor organization had induced the carriers' employees to engage in a concerted refusal to handle Aladdin's goods. As to Local 327, the record indicates that each driver made his own decision as to whether or not he would cross the picket line, and that there was no direction from the union on the subject..$^{80}$ Thus there was no inducement of the sort found by the Supreme Court to constitute a violation of $\S 8(\mathrm{~b})(4)(\mathrm{A})$ in its recent decision in Carpenters Union v. NLRB. ${ }^{81}$ Absent this inducement, the proviso in $\S 8(\mathrm{~b})(4)^{82}$

${ }^{77}$ For a discussion of involuntary servitude in relation to such an injunction consult note 105 infra. 1956).

78 Aladdin Industries, Inc. v. Associated Transport, Inc., 298 S.W. 2d 770, 775 (Tenn. App.,

79 "It shall be an unfair labor practice for a labor organization or its agents . . . to engage in, or to induce or encourage the employees of any employer to engage in, a strike or a concerted refusal in the course of their employment to use, manufacture, process, transport, or otherwise handle or work on any goods, articles, materials, or commodities or to perform any services, where an object thereof is ... forcing or requiring any employer or self-employed person to join any labor or employer organization or any employer or other person to cease using, selling, handling, transporting, or otherwise dealing in the products of any other producer, processor, or manufacturer, or to cease doing business with any other person. . . " 49 Stat. 452 (1935), as amended, 29 U.S.C.A. $\$ 158(\mathrm{~b})(4)(\mathrm{A})(1952)$.

${ }^{80}$ Transcript of Record, Bratton v. Aladdin Industries, Inc., at 543, 591, cited in Memorandum of Respondents in Answer to Petition for Writs of Certiorari at 11-12. For a discussion of who should find the facts consult text at note 72 supra. For a discussion of possible implications of the picketing by Local 327 subsequent to issuance of the injunctions consult text at note 90 infra.

${ }^{81} 357$ U.S. 93 (1958). For the holding in this case consult text following note 29 supra.

82 "Provided that nothing contained in this subsection shall be construed to make unlawful a refusal by any person to enter upon the premises of any employer (other than his own employer), if the employees of such employer are engaged in a strike ratified or approved by 
operates to take the drivers' refusal to cross the picket line out from under an unfair labor practice characterization. ${ }^{83}$ As to Local 5003, an unfair labor practice charge could also be made if it could be shown that that union had persuaded the truck drivers not to deal with Aladdin. As the facts developed, however, the only inducement present was an implied one supplied by the mere act of primary picketing by the striking Radio employees. This is certainly not the sort of inducement proscribed in Carpenters Union, ${ }^{84}$ and even if it were, the commission of an unfair labor practice by Local 5003 should have no bearing on the validity of state jurisdiction in an action having no restraining effect upon the activities of Local 5003 or its members.

As to the presence of activities protected under $\S 7$ of the Act, there being no employer-employee dispute between Aladdin and Local 327, no right to strike is involved. There is at issue only the right of carrier employees to refuse to cross a picket line established by employees of another employer. While labor has long had a hostile attitude toward handling "unfair" goods, ${ }^{85}$ the right to refuse to cross picket lines to handle such goods has not been established as one of the basic rights for the protection of which $\S 7$ is usually invoked, e.g., peaceful picketing in support of a lawful strike, self-organization, collective bargaining, right to strike. There has been no decision by the Court that refusing to cross another union's picket line is protected activity. Instead, the right to refuse is one which arises only from affirmative contractual provisions. If the collective bargaining agreement contains a probibition by way of a no-strike clause ${ }^{86}$ or if it contains no reference at all to such activity, ${ }^{87}$ the (carrier) employer is free to fire an employee who refuses to cross a picket line at the premises of another employer. Even where the collective bargaining agreement provides that employees shall not be required to cross such a picket line (the "hot-cargo" clause), as was the case in Aladdin, the employee could still be fired with recourse only to a contract action for damages. ${ }^{88}$

a representative of such employees whom such employer is required to recognize under this [Act] ..." 49 Stat. 454 (1935), as amended, 29 U.S.C.A. \$ 158(b)(4) (1952).

${ }^{83}$ This proviso, however, does not serve to carry the activity to the other extreme and make it protected. For further discussion of this proviso consult note 86 infra.

${ }^{84} \mathrm{In}$ fact, such incidental inducement was specifically approved in NLRB v. International Rice Mrilling Co., 341 U.S. 665 (1951).

${ }^{85}$ See Douglas, J., dissenting in Carpenters Union v. NLRB, 357 U.S. 93, 112 (1958).

${ }^{86}$ The proviso in $\S 8(\mathrm{~b})(4)$ enables the parties to a collective bargaining agreement to embody in their contract a provision against requiring an employee to cross a picket line. Nothing in the Act, however, prevents the parties from agreeing to contrary provisions, and where a no-strike clause has been included, an employee's breach of the clause in refusing to cross a picket line is unprotected activity. NLRB v. Rockaway News Supply Co., 345 U.S. 71, 80 (1953).

${ }^{87}$ In the absence of both a hot-cargo clause and a no-strike clause, the Board has upheld the firing of an employee who refused to obey company instructions and cross picket lines at other companies in the course of his duties, on the simple ground that the employee had refused to do the job for which he had been hired. Auto Parts Co., 107 N.L.R.B. 242 (1953).

${ }^{88}$ There is no direct holding on this point, but such would seem to be the necessary implication of the Court's holding in the Carpenters Union case, discussed in text at note 29 supra. If the employer is permitted to decide, when the occasion arises, whether or not he wishes to 
In no case should the employee's refusal be held to be protected activity. ${ }^{89}$ Accordingly, at the time the injunctions issued it would appear that there were no activities directly affected which could reasonably be held to be either protected or prohibited so as to deprive the state of jurisdiction. That subsequent union activity, i.e., the establishment of the token picket by Local 327,90 which gave rise to a contempt citation, might be construed in another context ${ }^{91}$ as an unfair labor practice ${ }^{92}$ should have no bearing on the validity of the injunction, nor on the issue of contempt. If the injunction is valid, ${ }^{93}$ the fact

The full impact of Aladdin, however, is appreciated only when the carriershipper problem is considered. The conclusion that the state injunction should be upheld rests upon a broader foundation than that the activity involved was neither protected nor prohibited. Whatever the decision as to the validity of this argument, it cannot be denied that the effect of the injunction is to put a restraint on certain concerted activity; if the enjoining of the carriers and their employees is to be effective, the truck drivers must not be permitted to do collectively what they cannot do individually, i.e., violate the injunction. The central issue in Aladdin is whether the fact that state action may incidentally touch upon labor matters serves to deprive the state from effectively requiring that the contempt conduct may also be prohibited conduct under the Act can offer no protection to those who flout the basic principles of judicial authority. ${ }^{94}$

abide by the hot-cargo clause, it would seem that, so far as national labor policy is concerned, the employee is in the same position as if the collective bargaining agreement had contained no such clause- with one reservation. Where the employer has failed to notify the employee, prior to discharge, that the hot-cargo clause is inoperative, it can be argued that the employer should be estopped to deny the validity of the clause in any Board proceeding concerned with the employee's reinstatement.

${ }^{89}$ The reservation in note 88 supra also applies to this statement.

${ }^{90}$ In deciding that the picket had not been placed at the Aladdin plant in good faith, the Tennessee court pointed out that (1) the picket did not appear until after the Chancellor had distinguished the American Tobacco case, (2) the organizational statement on the sign was in type too small to be read while the sign was being carried, and (3) Local 327 had never expressed any organizational desires either to Aladdin or to its employees. See Aladdin Industries, Inc. v. Associated Transport, Inc., 298 S.W.2d 770, 784-85 (Tenn. App., 1956).

${ }^{91}$ That is, had the token picketing been the subject matter of the injunction, rather than activity designed to induce violation of the injunction.

92 Which would follow if the Board holding in Curtis Brothers, Inc., 119 N.L.R.B. 232 (1957) were reinstated by the Supreme Court. For discussion of this case consult note 52 supra.

${ }^{93}$ It will also be shown that the injunction could not be flouted pending reversal even if the Supreme Court were ultimately to decide that the injunction was invalid because of preemption. See text at note 130 infra.

${ }^{94}$ Similar interference by unorganized private persons would unquestionably have given Tennessee jurisdiction to enter contempt citations. Federal policy does not provide any basis for reaching a contrary conclusion simply because labor organizations are involved. Cf. United Construction Workers v. Labunum Construction Corp., 347 U.S. 656, 669 (1954). Moreover, to permit a contrary result would have the effect of presenting unions with a back-door approach to the overturning of a form of judgment which the Supreme Court has consistently refused even to review. See note 63 supra. 
a common carrier to live up to its common law and statutory duty. ${ }^{95}$

This issue is part of the more general one as to when, and whether, a distinction should be made between labor regulations as such and state regulations of general application. ${ }^{96}$ Previous to the American Tobacco, Kerrigan and Aladdin per curiams, the Court had been presented with three types of such general state regulations: antitrust laws, public utility regulations, and prohibitions against violence. Injunctions were upheld only in the last of the three situations, ${ }^{97}$ and properly so. The public utility regulation before the Court in the Bus Employees case could be termed a law of general application only in the loosest sense, i.e., only insofar as it reflected the interest of all the people in keeping the public utilities operating. In both intent and application it was an anti-strike measure and was accordingly struck down as a direct interference with activities protected under $\$ 7$. The Missouri antitrust statute involved in Weber appeared in a somewhat better light since at least it was not by its terms directed solely at labor; nevertheless, its application under the circumstances had a direct effect on an employer-employee dispute. ${ }^{98}$ Thus neither case involved a situation where a state law of general application reasonably merited consideration apart from the labor problems involved. ${ }^{99}$

${ }^{95}$ This is the first time this issue has been presented to the Supreme Court in a pure form, with the labor conflict reduced to the bare minimum. The petitions in both Kerrigan and American Tobacco sought to enjoin the truck drivers' union involved, and in so doing in effect charged the union with an unfair labor practice, i.e., a secondary boycott. State enforcement of such petitions was clearly forbidden by the Weber decision, absent any consideration of the carrier-shipper problem. In addition, the injunction in American Tobacco was doubly defective, from the labor pre-emption standpoint, in that its enforcement required members of a local union to cross a picket line established by other members of the same local, since one local represented both the carrier employees and the striking employees of American Tobacco's subsidiary. The Court therefore considered that the Bus Employees case was also applicable. It is difficult to follow the Court on this point. The Bus Employees case was concerned with the right to strike guaranteed by $\$ \$ 7$ and 13 of the National Labor Relations Act. The Kentucky court, in American Tobacco, had not interferred with the strike as such but had simply enjoined the associated violence and restricted the number of pickets. The right to strike could be involved only if this right extended to all the members of a particular local, rather than only those members employed by the struck employer. In any event the analysis of the controlling effect of the carrier-shipper problem in Aladdin, which follows, should be equally applicable to Kerrigan and American Tobacco as well. Certainly state jurisdiction, if proper in the Aladdin situation, should not be pre-empted simply because of the jurisdictional idiosyncrasies of a Teamsters local.

${ }^{96}$ For further discussion of this larger problem, see Cox, Federalism in the Law of Labor Relations, 67 Harv. L. Rev. 1297, 1324 (1954), and Meltzer, The Supreme Court, Congress and State Jurisdiction over Labor Relations, 8 U. of Chi. L. S. Rec. Supp. 95, 110 (1958).

${ }^{97}$ The Court's policy of recognizing state power to control situations involving violence, actual or imminent, has been consistent through the various stages of development of federal labor pre-emption: (1) under the Wagner Act, in Allen Bradley Local No. $1111 \mathrm{v}$. Wisconsin Employment Relations Board, 315 U.S. 740 (1942); (2) following the Taft-Hartley amendments, in UAW v. Wisconsin Employment Relations Board, 351 U.S. 266 (1956); and (3) following the broadened pre-emptive doctrine established by Guss v. Utah Labor Relations Board, 353 U.S. 1 (1957), in Youngdahl v. Rainfair, Inc., 355 U.S. 131 (1957).

${ }^{98}$ In Aladdin, the relationship of the labor disputants (Radio and Local 5003) was not directly affected by the injunction.

${ }^{99}$ There is broad language in Weber which could indicate a refusal on the part of the Court to give any weight to arguments based upon state non-labor policies. It is clear from the 
The carrier-shipper aspect of Aladdin does present a non-labor policy meriting such consideration. At common law a common carrier and its employees owe a duty to serve all shippers alike and to receive, carry and deliver without discrimination whatever kind of goods the carrier holds itself out to transport. ${ }^{100}$ This duty has also been enacted into statutory law by the federal ${ }^{101}$ and state ${ }^{102}$ legislatures. Under both common law and statutory law, a shipper ${ }^{103}$ against whom a carrier has discriminated is entitled to an injunction compelling the

context, however, that the Court was not closing the door to the recognition of state intervention in a proper case. "Controlling and therefore superseding federal policy cannot be curtailed by the State even though the ground of intervention be different than that on which federal supremacy has been exercised." Weber v. Anheuser Busch, Inc., 348 U.S. 468, 480 (1955). This is short of the position that federal policy is always controlling. For recent dictum supporting this conclusion in the case of health and safety regulations, see Teamsters Union v. Oliver, 358 U.S. 283, 297 (1959).

${ }^{100}$ Missouri P. Ry. Co. v. Larabee Mills, 211 U.S. 612 (1909); Chicago, B. \& Q. Ry. Co. v. Burlington, C. R. \& N. Ry. Co., 34 Fed. 481 (S.D.Iowa, 1888); Toledo, A. A. \& N. M. Ry. Co. v. Pennsylvania Co., 54 Fed. 730 (N.D.Ohio, 1893); Pacific Gamble Robinson Co. v. Minneapolis \& St. L. Ry. Co., 83 F.Supp. 860 (D.Minn., 1949); Montgomery Ward \& Co. v. Northern Pacific Terminal Co., 128 F.Supp. 475 (D.Ore., 1953); Merchandise Warehouse Co. v. A.B.C. Freight Forwarding Corp., 42 L.R.R.M. 2686 (S.D.Ind., 1958); Burgess Bros. Co. v. Stewart, 112 Misc. 347 , 184 N.Y.S. 199 (1920), aff'd 114 Misc. 673, 187 N.Y.S. 873 (1921); Consolidated Freight Lines v. Department of Public Service, 200 Wash. 659, 94 P.2d 484 (1939); Burlington Transportation Co. v. Hathaway, 234 Iowa 135, 12. N.W.2d 167 (1943); Northwestern P. R. Co. v. Lumber \& Sawmill Workers Union, 31 Cal.2d 441, 189 P.2d 277 (1948). Although this duty has been characterized as an almost absolute one, it is generally held that the shipper's request must be reasonable and must not be made in a context of actual or imminent danger to carrier personnel. Minneapolis \& St. L. Ry. Co. v. Pacific Gamble Robinson Co., 215 F.2d 126 (C.A.8th, 1954). One federal district court and the Interstate Commerce Commission have further relaxed the duty and stated that the shipper's request was unreasonable when his plant was simply being picketed, even absent violence. S. E. Overton Co. v. Teamsters Union, 115 F.Supp. 764 (W.D.Mich., 1953); Montgomery Ward \& Co. v. Consolidated Freightways, 42 M.C.C. 225 (1943). This is definitely a minority position, and one from which the Commission appears to have withdrawn. It would seem implicit in the Commission's opinion in Galveston Truck Lines Corp. v. Ada Motor Lines, Inc., 73 M.C.C. 617 (1957), that nothing short of actual or imminent danger will relieve the carrier of its duty to provide non-discriminatory service.

10124 Stat. 380 (1887), as amended, 49 U.S.C.A. $\$ \$ 1(4), 3(1)$ (1952) (rail carriers); 49 Stat. 558 (1935), as amended, 49 U.S.C.A. $\$ \$ 316(\mathrm{~b}, \mathrm{~d})(1952)$ (motor carriers).

102 The Tennessee provisions pertinent in Aladdin were found in Tenn. Code Ann. (1955), $\S \S 65-512,65-514,65-1523,65-1524$.

${ }^{103}$ The picketed-shipper situation has also been handled by the carriers themselves obtaining injunctions against the shipper's employees (restraining their picketing directed against the carriers), Illinois Cent. R. Co. v. Teamsters Union, 90 F.Supp. 640 (W.D.La., 1950) (on theory of trespass); Louisville \& N. R. Co. v. Local Union No. 432, 104 F.Supp. 748 (S.D.Ala., 1952) (on theory of trespass); Terminal R. Ass'n v. International Ass'n of Machinists, 333 III.App. 288, 77 N.E.2d 448 (1948) (on theory of trespass); Northwestern P. R. Co. v. Lumber \& Sawmill Workers Union, 31 Cal.2d 441, 189 P.2d 277 (1948); Stewart v. State, 221 Ark. 496, 254 S.W.2d 55 (1953), in effect overruling Missouri P. R. Co. v. United Brick \& Clay Workers, 218 Ark. 707, 238 S.W.2d 945 (1951); and also against the union representing the carrier employees, Burlington Transportation Co. v. Hathaway, 234 Iowa 135, 12 N.W.2d 167 (1943). Except where trespass is involved, the first group of actions would appear to have been preempted by the National Labor Relations Act. Although the second technique is a variant on the Aladdin remedy, it is too close to the remedy struck down by the Court in Kerrigan to appear to have much future. 
carrier to perform its duty, ${ }^{104}$ and this injunction properly runs against the carrier's employees as well. ${ }^{105}$ In requiring the common carrier to serve without discrimination, neither the presence of a non-violent picket line which the carrier's employees refuse to cross, ${ }^{106}$ nor the mere threat of violence or a general

${ }^{104}$ In the following cases carriers were enjoined to maintain service in situations paralleling the Aladdin case: Chicago B. \& Q. Ry. Co. v. Burlington, C. R. \& N. Ry. Co., 34 Fed. 481 (S.D.Iowa, 1888); Toledo, A. A. \& N. M. Ry. Co. v. Pennsylvania Co., 54 Fed. 746 (N.D.Ohio, 1893); In re Missouri P. R. Co., 23 L.R.R.M. 2135 (E.D.Mo., 1948) (injunction issued following carrier trustee's request for instructions); Pacific Gamble Robinson Co. v. Minneapolis \& St. L. Ry. Co., 83 F. Supp. 860 (D.Minn, 1949); Merchandise Warehouse Co. v. A.B.C. Freight Forwarding Corp., 42 L.R.R.M. 2686 (S.D.Ind., 1958); Montgomery Ward \& Co. v. Sante Fe Trail Transportation Co., 42 M.C.C. 212 (1943) (picketing was not at shipper's plant but at dock of local delivery carrier to whom shipper had transferred business, which was Commission's basis of distinction in the Consolidated Freightways case decided the same day); Burgess Bros. Co. v. Stewart, 114 Misc. 673, 187 N.Y.S. 873 (1921); Consolidated Freight Lines v. Department of Public Service, 200 Wash. 659, 94 P.2d 484 (1939) (suspension of state operating permit); Beck \& Gregg Hardware Co. v. Cook, 210 Ga. 608, 82 S.E.2d 4 (1954). Only two cases have been noted in which injunctions (or, rather, cease-and-desist orders) were denied solely on the ground that picketing of shipper's plant relieved the carrier of its common law and statutory duty, Montgomery Ward \& Co. v. Consolidated Freightways, 42 M.C.C. 225 (1943) and Montgomery Ward \& Co. v. Chicago, M., St. P. \& P. R. Co., 268 I.C.C. 257 (1947), which cited Consolidated Freightways as precedent. For a discussion of the present Commission position consult note 100 supra. Injunctions have also been denied because of procedural defects, P. Reardon, Inc. v. Caton, 189 App.Div. 501, 178 N.Y.S. 713 (1919); Reardon v. International Mercantile Marine Co., 189 App. Div. 515, 178 N.Y.S. 722 (1919) (grant of injunction in these cases essentially was reversed for failure to join carriers and employees in the same action); because of pre-emption aspects of the Shipping Act not found in the Interstate Commerce Act or the Motor Carriers Act, New York Lumber Trade Ass'n v. Lacey, 245 App.Div. 262, 281 N.Y.S. 647 (1935); and because of the limitations of the NorrisLaGuardia Act, Lee Way Motor Freight v. Keystone Freight Lines, 126 F.2d 931 (C.A.10th, 1942); Southeastern Mrotor Lines v. Hoover Truck Co., 34 F.Supp. 390 (M.D.Tenn., 1940); S. E. Overton Co. v. Teamsters Union, 115 F.Supp. 764 (W.D.Mich. 1953). The federal courts, however, are not in agreement on the applicability of the Norris-LaGuardia Act to this situation. While courts in the Sixth and Tenth Circuits have held that the Act prevents enjoining of carriers, courts in the Seventh and Eighth Circuits have decided that there is no labor dispute in the Aladdin situation within the meaning of $\S 13$.

${ }^{105}$ This is true whether or not the employee was a party to the suit, provided he had notice that the injunction had issued. In re Lennon, 166 U.S. 548, 554 (1897); Toledo, A. A. \& N. M. Ry. Co. v. Pennsylvania Co., 54 Fed. 746, 750 (N.D.Ohio, 1893). The few courts which have considered the involuntary servitude possibilities of this aspect of the injunction against a carrier have dismissed the problem as unreal. Such an injunction does not prohibit any employee from quitting his job. So long as he chooses to work in a field with the strict duties found in common carriage, however, he is required to assume certain obligations among which is the duty to serve the public without discrimination. In re Lennon, 166 U.S. 548, 555 (1897); Toledo, A. A. \& N. M. Ry. Co. v. Pennsylvania Co., 54 Fed. 730,742 (N.D.Ohio, 1893); Burgess Bros. Co. v. Stewart, 112 Misc. 347, 360, 184 N.Y.S. 199, 207 (1920); aff'd 114 Misc. 673, 677, 187 N.Y.S. 873, 876 (1921). Cf. UAW v. Wisconsin Employment Relations Board, 336 U.S. 245, 251 (1949).

${ }^{106}$ In re Missouri R. R. Co., 23 L.R.R.M. 2135 (E.D.Mo., 1948); Pacific Gamble Robinson Co. v. Minneapolis \& St. L. Ry. Co., 83 F.Supp. 860, 862 (D.Minn., 1949); Montgomery Ward \& Co. v. Northern Pacific Terminal Co., 128 F.Supp. 475, 507-8, 512-13 (D.Ore., 1953) (damage action); Merchandise Warehouse Co. v. A.B.C. Freight Forwarding Corp., 42 L.R.R.M. 2686 (S.D. Ind., 1958); Montgomery Ward \& Co. v. Santa Fe Trail Transportation Co., 42 MI.C.C. 212 (1943); Consolidated Frreight Lines v. Department of Public Service, 200 Wash. 659, 94 P.2d 484 (1939); Burlington Transportation Co. v. Hathaway, 234 Iowa 135, 12 N.W.2d 167 (1943); Beck \& Gregg Hardware Co. v. Cook, 210 Ga. 608, 613, 82 S.E.2d 4, 9 (1954). Contra: Montgomery Ward \& Co. v. Consolidated Freightways, 42 M.C.C. 225 (1943), 
strike in the event the carrier's employees are forced to cross ${ }^{107}$ has been held to be a valid defense, even where the carrier's tariff contained a standard impossibility clause. ${ }^{108}$ In particular the carrier has been held unable to contract out of its duties toward the public by the inclusion of a hot-cargo clause in the collective bargaining agreement with its employees. ${ }^{109}$

To date, only a few courts have analyzed the inter-relationship of transportation policy and labor policy involved in the Aladdin situation. With but one exception, ${ }^{110}$ however, the conclusion has been that the labor aspects may be subordinated to transportation considerations. ${ }^{111}$ Moreover, such clues as the Supreme Court has supplied in its recent decision in Carpenters Union v. $N L R B^{112}$ indicate that it too would favor such an approach under the proper circumstances.

The Court was there presented with the argument that a hot-cargo clause in a collective bargaining agreement with a common carrier should be invalid at

and Montgomery Ward \& Co. v. Chicago, M. St. P. \& P. R. Co., 268 I.C.C. 257 (1947), as to which see notes 100 and 104 supra.

${ }^{107}$ Chicago, B. \& Q. Ry. Co. v. Burlington, C. R. \& N. Ry. Co., 34 Fed. 481, 484 (S.D.Iowa, 1888); Burgess Bros. Co. v. Stewart, 112 Misc. 347, 355, 184 N.Y.S. 199, 204 (1920), aff'd 114 Misc. 673, 680, 187 N.Y.S. 873, 877 (1921); In re Missouri P. R. Co., 23 L.R.R.M. 2135 (E.D.Mo., 1948); Pacific Gamble Robinson Co. v. Minneapolis \& St. L. Ry. Co,, 83 F.Supp. 860, 862 (D.Minn., 1949); 105 F.Supp. 794 (D.Minn., 1952), aff'd 215 F.2d 126 (C.A.8th, 1954) (damage action); Montgomery Ward \& Co. v. Northern Pacific Terminal Co., 128 F.Supp. 475, 515 (D.Ore., 1953) (damage action); Merchandise Warehouse Co. v. A.B.C. Freight Forwarding Corp., 42 L.R.R.M. 2680 (S.D.Ind., 1958).

${ }^{108}$ The tariff clause in the Aladdin case provided as follows: "Where strikes, picketing, riots or other labor disturbances, or where conditions of streets, roadways, alleys, yards or the exterior or interior of premises make it impracticable, unsafe, or impossible to render pick-up and/or delivery service, such service will not be given." Aladdin Industries, Inc. v. Associated Transport, Inc., 298 S.W.2d 770, 776 (Tenn.App., 1956). In addition to finding no evidence that any of the specified conditions existed, the Tennessee court pointed out that this tariff provision could be invoked only by a carrier (which was not done) and was of no benefit to carrier employees.

${ }^{109}$ Montgomery Ward \& Co. v. Northern Pacific Terminal Co., 128 F.Supp. 475, 498-99 (D.Ore., 1953) (damage action); Merchandise Warehouse Co. v. A.B.C. Freight Forwarding Corp., 42 L.R.R.M. 2686 (S.D.Ind., 1958); Galveston Truck Line Corp. v. Ada Motor Lines, Inc., 73 M.C.C. 617 (1957); Beck \& Gregg Hardware Co. v. Cook, 210 Ga. 608, 015, 82 S.E.2d 4, 9 (1954). Contra: S. E. Overton Co. v. Teamsters Union, 115 F.Supp. 764 (W.D.Mich., 1953), but the court there was so wrapped up in the labor aspects of the case that it never got around to any real analysis of the common carrier duties involved; the court's position on the Norris-LaGuardia Act alone was sufficient to dispose of the case.

${ }^{110}$ The view taken in S. E. Overton Co. v. Teamsters Union, 115 F.Supp. 764 (W.D.Mich., 1953), that the transportation issue was subordinate to the labor aspect was undoubtedly influenced by the fact that the shipper not only had alleged an unfair labor practice in his petition but also had substantially the same charge pending before the NLRB.

111 Minneapolis \& St. L. Ry. Co. v. Pacific Gamble Robinson Co., 215 F.2d 126, 138 (C.A.8th, 1954) (damage action); Montgomery Ward \& Co. v. Northern Pacific Terminal Co., 128 F.Supp. 475, 498 (D.Ore., 1953) (damage action); Burlington Transportation Co. v. Hathaway, 234 Iowa 135, 12 N.W.2d 167 (1943); Northwestern P. R. Co. v. Lumber \& Sawmill Workers Union, 31 Cal.2d 441, 189 P.2d 277 (1948); Beck \& Gregg Gardware Co. v. Cook, $210 \mathrm{Ga} .608,615$, 82 S.E.2d 4, 9 (1954).

112357 U.S. 93 (1958). 
its inception on the ground that in entering such an agreement the carrier had violated its obligations to provide non-discriminatory service. ${ }^{113} \mathrm{Such}$ a position had already been taken by the NLRB in Genuine Parts Co.114 and appeared to have received support from a subsequent Interstate Commerce Commission ruling in Galveston Truck Lines Corp. v. Ada Motor Lines, Inc., ${ }^{15}$ that common carriers were not relieved of their statutory obligations by a hot-cargo clause. The Court pointed out, however, that the Commission had concerned itself, not with the legality of hot-cargo clauses in the abstract, but only with the validity of a hot-cargo clause as a defense to a specified charge of violation of statutory duty under the Interstate Commerce Act. The Court stated that the Commission had the primary responsibility, at least as between itself and other agencies of the federal government, of determining whether a carrier could be relieved of its usual statutory duty, and the Court refused to complicate the administration of the Interstate Commerce Act by laying down as a universal rule what the Commission might prefer to consider on an ad hoc basis. Instead, it simply decided that in an action before the NLRB the existence of a hotcargo clause was no defense to what otherwise was clearly an unfair labor practice. ${ }^{116}$

In the course of its opinion, the Court made it clear that where transportation policy was the primary issue, it could properly be considered apart from possible labor overtones, ${ }^{117}$ in the absence of protected or prohibited activities. ${ }^{118}$ At least this approach would be proper where transportation policy was being applied by a federal agency. Even if this is as far as the Court is willing to go, it would have to dispose of Aladdin on grounds apart from those expressed in Kerrigan and American Tobacco. And in so doing, it would be forced to deal with the very muddled issue of the pre-emptive aspects of the Interstate Commerce Act.

Only brief mention will be made of this pre-emption point..119 The basis for ${ }^{113}$ Id., at 108. 114119 N.L.R.B. 399 (1957). 11573 M.C.C. 617 (1957).

116 For further discussion of this case see text at note 29 supra.

117 "Whether a carrier has without justification failed to provide reasonable and nondiscriminatory service is a question of defining the carrier's duty in the frametwork of the national transportation policy. Whether there is a 'strike or concerted refusal,' or a 'forcing or requiring' of an employee to cease handling goods is a matter of the federal policy governing labor relations. The Board is not concerned with whether the carrier has performed its obligations to the shipper, but whether the union has performed its obligations not to induce employees in the manner proscribed by $\S 8(\mathrm{~b})(4)(\mathrm{A})$. Common factors may emerge in the adjudication of these questions, but they are, nevertheless, distinct questions involving independent considerations. This is made clear by a situation in which the carrier has freely agreed with the union to engage in a boycott. He may have failed in his obligations under the Interstate Commerce Act, but there clearly is no violation of $\S \delta(\mathrm{b})(4)(\mathrm{A})$; there has been no prohibited inducement of employees." Carpenters Union v. NLRB, 357 U.S. 93, 110-111 (1958).

${ }_{118}$ The general tone of the Court's opinion, moreover, implies that such subordination would be approved even in the presence of prohibited activities. There is nothing in the opinion to indicate that that part of the case which concerned the common carrier could not have been treated by the Commission had it been presented with the case instead of the Board.

110 For further discussion of the subject, see Duty of Common Carrier to Cross Picket Line of Shipper's Employees to Receive Good for Carriage, 67 Harv. L. Rev. 317 (1953). 
any finding of pre-emption must rest upon the statutory provisions requiring carriers to furnish transportation upon reasonable request and not unjustly and unreasonably to discriminate among shippers. ${ }^{120}$ If they stood alone there would be strong argument that these and other provisions ${ }^{121}$ of this comprehensive statute codified the rights and duties of common carriers to such an extent as to suspend the common law duties of carriers. What might have been a clear case favoring pre-emption was, however, rendered ambiguous by $\S 22$, and later $\S 317(j)$, which preserved to interested parties their common law remedies. ${ }^{122}$ At first reading, these various provisions are not altogether harmonious. Nevertheless, the Court has decided that Congress intended all sections to be operative and that the manifest purpose of $\S 22$ was to make it clear that such appropriate common law or statutory remedies as were consistent with the scheme and purpose of the Act were not abrogated and could be enforced by either federal or state courts. ${ }^{123}$ In this multi-jurisdiction situation, the Court has held that resort to the Commission is required where a rule or practice is attacked as unreasonable or discriminatory. ${ }^{124}$ Where, on the other hand, the issue concerns a discriminatory application of a rule fair on its face, resort to the Commission in the first instance is not required..$^{125}$

Although the Commission has considered a number of charges of discrimination growing out of a carrier's failure to provide non-discriminatory service across a shipper's picket line, ${ }^{126}$ the pre-emption issue to date has reached the

12024 Stat. 380 (1887), as amended, 49 U.S.C.A. $\$ \S 1(4), 3(1)$ (1952) (rail carriers); 49 Stat. 558 (1935), as amended, 49 U.S.C.A. $\$ \S 316(\mathrm{~b}, \mathrm{~d})(1952)$ (motor carriers).

${ }^{121}$ Section 8 of the Act gives a private right of action for damages occasioned by the doing of a prohibited act, and $\S 9$ provides that the injured party may, at his election, either bring a complaint before the Commission or bring suit for damages in any district court. 24 Stat. 380 (1887), as amended, 49 U.S.C.A. $\$ \$ 8,9$ (1952).

122 As to rail carriers, 24 Stat. 387 (1887), as amended, 49 U.S.C.A. $\S 22$ (1952), provides: "... nothing in this chapter contained shall in any way abridge or alter the remedies now existing at common law or by statute, but the provisions of this chapter are in addition to such remedies. ..." As to motor carriers, 49 Stat. 560 (1935), as amended, 49 U.S.C.A. $\$ 316(\mathrm{j})$ (1952), provides: "Nothing in this section shall be held to extinguish any remedy or right of action not inconsistent herewith."

${ }^{123}$ Pennsylvania R. Co. v. Sonman Coal Co., 242 U.S. 120, 123 (1916).

${ }_{124}$ Texas \& P. Ry. Co. v. Abilene Cotton Oil Co., 204 U.S. 426 (1907); Baltimore \& O. R. Co. v. United States ex rel. Pitcairn Coal Co., 215 U.S. 481 (1910); Robinson v. Baltimore \& O. R. Co., 222 U.S. 506 (1912); Mitchell Coal \& Coke Co. v. Pennsylvania R. Co., 230 U.S. 277 (1913); Northern P. R. Co. v. Solum, 247 U.S. 477 (1918); Midland V. R. Co. v. Barkely, 276 U.S. 482 (1928); Lewis, Simmis, Jones Co. v. Southern P. Co., 283 U.S. 654 (1931); Armour \& Co. v. Alton R. Co., 312 U.S. 195 (1941); United States v. Wabash R. Co., 321 U.S. 403 (1944).

${ }^{125}$ Missouri P. Ry. Co. v. Larabee Mills, 211 U.S. 612 (1909) (no strike involved); Pennsylvania R. Co. v. Puritan Coal Mining Co., 237 U.S. 121 (1915) (no strike involved); Pennsylvania R. Co. v. Sonman Coal Co., 242 U.S. 120 (1910) (no strike involved); Pacific Gamble Robinson Co. v. Minneapolis \& St. I. Ry. Co., 83 F.Supp. 860 (D.Minn., 1949); 105 F.Supp. 794 (D.Miss., 1952), aff'd 215 F.2d 126 (C.A.8th, 1954); Montgomery Ward \& Co. v. Northern Pacific Terminal Co., 128 F.Supp. 475 (D. Ore., 1953); Beck \& Gregg Hardware Co. v. Cook, 210 Ga. 608, 82 S.E.2d 4 (1954). It should be noted that only the first Pacific Gamble case and the Beck \& Gregg case involved the elements of both picket line and injunction.

${ }^{126}$ E.g., Pick Up Delivery Restrictions in Official Territory, 269 I.C.C. 191 (1947); Planters Nut \& Chocolate Co. v. American Transfer Co., 31 M.C.C. 719 (1942); Montgomery Ward 
Supreme Court only in the context of discrimination allegations not involving failure of carrier employees to cross such picket lines. ${ }^{127}$ If the Court should choose to come to grips with the issue in the context of the Aladdin situation, there are two possible approaches it could take. An "impossibility" clause, such as found in the Aladdin case, ${ }^{128}$ could be said to have established a carrier rule against crossing picket lines, the reasonableness of which would have to be decided in the first instance by the Commission. ${ }^{129}$ On the other hand, where the carriers refuse to raise such a clause in defense-again, the Aladdin situationthere could be implied a general practice of service to all shippers, irrespective of picket lines, so that the reasonableness of a specific deviation from this practice could be determined by a state court.

Yet as the case was presented to it, the Court could have affirmed without resolving either pre-emption issue. The fact that it was presented not with the injunction itself but with criminal contempt convictions resulting from violation of the injunction should have been determinative. The evidence showed clearly that the refusals of the individual truck drivers to cross the picket line was in deliberate disobedience of the injunction. ${ }^{130}$ Regardless of whether the injunction was irregular or erroneous and thus might eventually be overturned in appellate proceedings, while it was in force it had to be obeyed ${ }^{131}$ since it did not rest upon a frivolous assertion of jurisdiction. Not only is this position supported as to Tennessee injunctions by Nashville Corp. v. United Steelworkers, ${ }^{132}$ but it was one of the grounds ${ }^{133}$ used by the Supreme Court to uphold the con-

\& Co. v. Santa Fe Trail Transportation Co., 42 M.C.C. 212 (1943); Montgomery Ward \& Co. v. Consolidated Freightways, 42 M.C.C. 225 (1943); Montgomery Ward \& Co., v. Chicago, M., St. P. \& P. R. Co., 268 I.C.C. 257 (1947).

${ }^{127}$ This, of course, excludes Kerrigan and American Tobacco, in which the Supreme Court never even had occasion to consider this pre-emption issue.

${ }^{128}$ For the text of this tariff clause consult note 108 supra.

${ }^{129}$ See Harv. L. Rev., op. cit. supra note 119, at 326.

${ }^{130}$ Aladdin Industries, Inc. v. Associated Transport, Inc., 298 S.W.2d 770, 774 (Tenn. App., 1956).

${ }^{131}$ See Cox, The Void Order and the Duty to Obey, 16 U. of Chi. L. Rev. 86, 113 (1948), where it is suggested that "the general rule should be that it is the duty of the litigant to obey all orders made by a court having jurisdiction of his person, pendente lite, regardless of the decision that is made with respect to the ultimate validity of these orders, with this exception: If the litigant has exhausted all the normal methods of appellate review and if obedience to the order will substantially and irrevocably injure legal interests of the litigant that are not remote and abstract in character, then the litigant should be entitled to take his chance on the invalidity of the order." The limitation proposed by Professor Cox would not encompass the Aladdin situation since the carrier employees could not have been seriously prejudiced had they obeyed the injunction and Local 327 and its president were not even parties to the basic litigation.

132187 Tenn. 444, 215 S.W.2d 818 (1948).

${ }^{133}$ Though presented as an alternative ground by Chief Justice Vinson in an opinion for a Court that was divided four ways on four different issues, it was not dictum but was essential to the determination of the case. Although five justices decided that the injunction had been properly granted, only three of this group were willing to uphold the fines for criminal contempt. Therefore, the latter holding required the support of two justices who had agreed only 
tempt convictions reviewed in United States v. United Mine Workers. ${ }^{134}$ In his concurring opinion, Mr. Justice Frankfurter discussed at length the "void but non-frivolous" injunction and concluded that, short of an indisputable want of authority, the very existence of a court presupposed its power to decide whether a case was properly before it and to issue appropriate orders which would afford fair time for consideration while existing conditions were preserved. ${ }^{\mathbf{1 3 5}}$

The pre-emption issue involved in Aladdin has no obvious solution. The Court has recognized that the scope of pre-emption by way of protected or prohibited activities is not susceptible of precise delimitation ${ }^{136}$ and that there is left to the Court a continuing task of judicial inclusion and exclusion. ${ }^{137}$ Accordingly, it would seem that violations of injunctions based on activity in the border-line region should always bring into operation the United Mine Workers doctrine. ${ }^{138}$ The activity in Aladdin fell into this region, at the very least. If the Supreme Court made nothing else clear, it is obvious from its remand of the case for further consideration that it did not find state jurisdiction unquestionably pre-empted.

Upon reconsideration by the Tennessee court, the contempt convictions were reaffirmed, ${ }^{139}$ and it is presumed that the case is once more on its way to the Supreme Court. It is to be hoped that the Court will analyze in a full opinion the complexities of a case which presents situations clearly distinguishable from Kerrigan and American Tobacco, labor pre-emption issues not settled by $W e b e r$, and transportation pre-emption issues of first impression, and which, in the last

that the injunction was "void but non-frivolous." See Watt, The Divine Right of Government by Judiciary, 14 U. of Chi. L. Rev. 409, 422-23, 437 (1947).

${ }^{134} 330$ U.S. 258 (1947).

${ }^{135}$ Id., at 309-311. As an indication that the federal district court had not been engaged in a frivolous inquiry into jurisdiction that had obviously been withheld (the issue being whether the Norris-LaGuardia Act applied to an attempt by the United States to enjoin the UMW from striking at a time when the government operated the mines), Mr. Justice Frankfurter pointed to the extended arguments, lengthy briefs and considerable research which had been a necessary prelude to the Court's decision.

136 Weber v. Anheuser-Busch, Inc., 348 U.S. 468, 480 (1955).

${ }^{137}$ Amalgamated Clothing Workers v. Richman Bros., 348 U.S. 511, 516 (1955).

${ }^{138}$ Thus, it would be necessary only for the Court to determine that jurisdiction over the activity enjoined had not clearly been pre-empted under prior decisions. If only criminal contempt convictions were presented, there would be no need to determine upon which side of the line the underlying injunction lay until it had been presented in a proper form for the Court's consideration. As a practical matter, however, the Court would undoubtedly go ahead and determine the validity of the injunction, even though the latter were only preliminary in form.

${ }^{139}$ Aladdin Industries, Inc. v. Associated Transport, Inc., 42 L.R.R.M. 2674 (Tenn.App., 1958). The court distinguished Kerrigan by pointing out that (1) no unfair labor practice had been alleged in the petition for the injunction, (2) the acts of contempt involved conduct neither protected nor prohibited under the Act since the truck drivers by their own admission were acting individually and not in concert, and (3) in any event, the injunction must be obeyed until set aside. See note 65 supra. Duty to obey is discussed further in 43 L.R.R.M. 2573 (Tenn.App., 1958), denying petition for rehearing. 
analysis, would appear to come under the obedience doctrine of United Mine Workers. As unhelpful as the per curiam was in the first instance, serving only to delay a final determination while the state court made the obvious response to the Court's direction, a final disposition by way of a per curiam, except for a per curiam affirmance grounded on United Mine Workers, would seem very unwise.

\section{B. SCOPE OF THE FTC'S POWER OVER THe INSURANCe BUSINEsS}

The McCarran Act provides in part that "the Federal Trade Commission Act, as amended, shall be applicable to the business of insurance [only] to the extent that such business is not regulated by state law."140 The impact of this statute upon the FTC's power to investigate and regulate the activities of interstate insurance companies was delineated in a somewhat confusing fashion by two per curiam opinions ${ }^{141}$ in the October, 1957 term.

In FTC v. Crafts $^{142}$ the Commission, purporting to act under the broad authority conferred upon it by the Federal Trade Commission Act, ${ }^{143}$ had issued a complaint alleging that the Firemen's Fund Indemnity Co. was disseminating false and misleading advertising. A subpoena was issued ordering the company's president to testify and produce records. The president refused, arguing that because each of the forty-eight states regulated the advertising of insurance the McCarran Act had withdrawn the FTC's power to investigate such advertising. The Commission then obtained an enforcing order from a federal district judge who apparently yielded to the argument that he lacked jurisdiction to decide whether the FTC had authority to conduct the investigation. The Ninth Circuit Court of Appeals reversed. ${ }^{144}$ That court recognized as well settled the doctrine that an administrative agency may determine conclusively, for the purposes of making an investigation, whether a certain business or state of facts is within the ambit of its power. It was said, however, that that doctrine was limited to questions of "coverage" as contrasted with "jurisdiction." In coverage cases, the court explained, the agency has been vested with power over a broad range of activities; in jurisdiction cases the agency's power has been narrowly delimited if not abolished by a congressional enactment. The McCarran Act was said to bring the Crafts case within the latter category. However, although it held that the district court had the power to determine whether the FTC had jurisdiction, the court of appeals ordered the case dismissed because the Commission had not particularized its demands so that a determination could be made as to which documents pertained to areas over which the Commission had authority.

The Supreme Court reversed, ${ }^{145}$ citing only Endicott Johnson Corp. v. Per-

14059 Stat. 34 (1945), 15 U.S.C.A. \$1012(b) (1948).

1.41 FTC v. Crafts, 355 U.S. 9 (1957), and FTC v. National Casualty Co., 357 U.S. 560 (1958).

142355 U.S. 9 (1957), rev'g 244 F.2d 882 (C.A.9th, 1957).

${ }^{443} 38$ Stat. 717 (1914), as amended, 15 U.S.C.A. $\$ 41$ (1951).

${ }^{144}$ Crafts v. Federal Trade Commission, 244 F.2d 882 (C.A.9th, 1957).

145 FTC v. Crafts, 355 U.S. 9 (1957). 
kins ${ }^{146}$ and Oklahoma Press Publishing Co. v. Walling, ${ }^{147}$ cases which the court of appeals had distinguished as involving only coverage. In the Endicott Johnson case the dispute was whether certain plants were doing work which would bring them within the minimum wage provisions of the Walsh-Healey Public Contracts Act; in the Oklahoma Press case the question was whether certain employees were engaged in producing goods for interstate commerce so that the FLSA governed wage rates. In each case the documents subpoened were necessary to a determination of both coverage and statutory violation. The Supreme Court held that the administrative agency could subpoena records and make a determination of coverage which was conclusive during the period of investigation.

Since neither the narrow nor the broad rationale of the Endicott Johnson and Oklahoma Press cases seem applicable, it is far from clear why the mere citation of those cases should be thought adequate grounds for reversal in the Crafts case. The narrow rationale, that agencies should not be forced to participate in trials about coverage without benefit of the documents essential to that issue, cannot be the basis for the Crafts decision since there the agency's power depended only upon construction of a statute. Seemingly no more applicable is the broad rationale that Congress, in providing for administrative enforcement of a statute, empowers the agency to determine initially whether particular conduct comes within the statute's scope. In Crafts there was no dispute whether particular conduct was within the agency's power; the statutory basis for any authority of the agency over an entire range of activities was challenged. This distinction, inarticulately phrased by the Ninth Circuit as a difference between coverage and jurisdiction, is one between a factual determination and statutory construction. Although an agency may be the appropriate body to handle the former, a court seems best fitted for the latter. This analysis seems strengthened by Section 6(c) of the Administrative Procedure Act which requires a district court to sustain an agency's subpoena only "to the extent that it is found in accordance with the law."148 An agency investigation of a particular field cannot have any "lawful" purpose unless there is a law conferring

146317 U.S. 501 (1943).

147327 U.S. 186 (1946).

14860 Stat. 240 (1946), 5 U.S.C.A. $\$ 1005$ (c) (Supp., 1950). As originally introduced that section provided that in a contest over the validity of an administrative subpoena, a district court should "... determine all relevant questions of law raised by the parties, including the authority or jurisdiction of the agency. ..." Sen. Doc. No. 248, 79th Cong. 2d Sess. 158 (1946). The deliberate omission of this provision and the insertion of "in accordance with law" would appear to be a legislative enactment of the Endicott Johnson rule. This interpretation is supported by the House and Senate Judiciary Committee reports. In substantially the same language later used by the House Committee Report, the Senate Committee commented on Section 6(c) as follows: "The subsection constitutes a statutory limitation upon the issuance or enforcement of subpoenas in excess of agency authority or jurisdiction. This does not mean, however, that courts should enter into a detailed examination of facts and issues which are committed to agency authority in the first instance, but should, instead, inquire generally into the legal and factual situation and be satisfied that the agency could possibly find that it has jurisdiction." Id., at 206. The only case to consider the problem of coverage since the enactment of Section 6(c) also supports the interpretation given. Tobin v. Banks \& Rumbaugh, 201 F.2d 223 (C.A.5th, 1953). 
upon the agency authority to investigate that field. Congress therefore appears to have taken the position that a court is the proper body to determine whether an agency is acting conformably to its authorizing statute. It is thus puzzling that the Supreme Court summarily disposed of Crafts.

The puzzle is made more complex by the other per curiam decision involving the FTC's power over interstate insurance. In a lengthy opinion the Court in FTC v. National Casualty $\mathrm{Co}^{149}$ nullified cease and desist orders against certain alleged false advertising practices. The Court rejected the FTC's contention that the McCarran Act did not withdraw the Commission's authority unless the states effectively applied their regulations through administrative bodies. The Court stated that it was sufficient that the states enacted legislation prohibiting misleading insurance advertisements. If a glance at the statute books after the investigation in National Casualty convinced the Court that the FTC clearly had no jurisdiction, it may reasonably be asked why it should not have been equally clear before the Crafts investigation. In both cases the FTC's authority depended solely upon a construction of the McCarran Act. Neither case contains any indication how the Court reconciles the two. However, it may be possible to make the two stand together by comparing the precise language in the National Casualty case with the language of the McCarran Act. The Court referred to the Commission's authority to regulate, the only aspect of the FTC's power involved in the case. It may be argued that the McCarran Act was designed only to restrict the FTC's power to regulate, not to investigate. This interpretation is easily justified since it would leave the FTC free to gather facts for later presentation to Congress should it appear that the public interest no longer is compatible with giving the states primary authority to regulate the insurance business. Herein may be found the unspoken rationale of the Craft case.

\section{Jodictax Review of the Form of Mitutary Discharges}

In Harmon v. Brucker, ${ }^{150}$ a three page per curiam opinion accompanied by a dissent of equal length by Justice Clark, the Court disposed of the consolidated cases of two soldiers who had been given other than honorable discharges. ${ }^{151}$ The Secretary of the Army had not based the form of the discharges exclusively upon the military service of the soldiers, but rather had taken into account preinduction activities. The two men, Harmon and Abramowitz, sued to nullify the discharges and to obtain an order commanding the issuance of honorable discharges. The district courts dismissed the actions and the court of appeals affirmed, ${ }^{152}$ holding that the form of a discharge is not subject to judicial review.

${ }^{149} 357$ U.S. 650 (1958), aff'g National Casualty Co. v. FTC, 245 F.2d 883 (C.A.6th, 1957), and American Hospital \& Life Insurance Co. v. FTC, 243 F.2d 719 (C.A.5th, 1957).

150355 U.S. 579 (1958), rev'g Harmon v. Brucker, 243 F.2d 613 (App.D.C., 1957), and Abramowitz v. Brucker, 243 F.2d 834 (App.D.C., 1957).

151 Harmon had received a general discharge (under honorable conditions), Abramowita, an undesirable discharge.

152 Harmon v. Brucker, 243 F.2d 613 (App.D.C., 1957), aff'g 137 F.Supp. 475 (D.D.C., 1956); Abramowitz v. Brucker, 243 F.2d 834 (App.D.C., 1957), aff'g an unreported district court decision. 
The Supreme Court reversed, deciding, first, that judicial review may be secured if a person has been injured by a government official acting in excess of his authority and, second, that the Secretary of the Army had exceeded his statutory authority in basing his decision on pre-induction records. ${ }^{153}$

Although the soundness of the second holding may be questioned, ${ }^{154}$ its scope is well-defined: the statutes and regulations in effect at the time the determinations were made in the Harmon and Abramowitz cases gave the Secretary of the Army no authority to base the form of a discharge on incidents occurring prior to military service. The reach of the first holding is more difficult to measure. The statute which establishes a board to review the form of administrative discharges provides that "[T]he findings [of the board of review] shall be final subject only to review by [the Secretary]."155 The Court's opinion did not explicitly deal with this statute, but the Court must have construed it as not precluding judicial review where it was claimed there was an injury caused by an action taken by the Secretary of the Army in excess of his authority.

This construction covers the extreme case. However, since the Court did not articulate its reading of the statute, it is impossible to predict whether judicial review is proper in less extreme cases. It may be argued that the Court would permit such review. For the statute may be read as applying only to administrative proceedings. The only precedents which might be urged against allowing judicial review, the cases holding there is no right to judicial review of the giving of discharges, ${ }^{156}$ could easily be distinguished. For the Army is entitled to absolute control over its membership, but no such unrestrained power is needed over the form of discharges, a matter which has an important impact on civilian life.

${ }^{153}$ Harmon v. Brucker, 355 U.S. 579 (1958).

${ }^{154}$ The Solicitor General apparently conceded the merits of the case. Id., at 582 . However, the Court made its own determination. The Court's decision rested primarily upon a clause in 58 Stat. 286 (1944), 38 U.S.C.A. 693h (1954) which stated that review of the form of a discharge should be based on "... all available records of the service department. . .." The Court seems to have erred in excluding from the sweep of the statutory language reports of prior activities kept with the servicemen's files. Furthermore, the power to determine the conditions of discharge is not conferred by Section 693, which relates only to the establishment of review boards and the procedure for reviewing discharges, but rather by 70A Stat. 220 (1956), 10 U.S.C.A. $§ 3811$ (1958) (formerly 64 Stat. 145 [1950], 10 U.S.C.A. § 652a [1952]). Section 3811 leaves the matter of administrative discharges to the Secretary of the Army. It is therefore difficult to see how the Secretary could exceed his authority.

15558 Stat. 286 (1944), 38 U.S.C.A. $\$ 693 \mathrm{~h}$ (1958). It has been held that this statute "at the very least" precludes review of allegedly erroneous findings of fact. Gentila v. Pace, 193 F.2d 924 (App.D.C., 1951), cert. denied 342 U.S. 943 (1952).

${ }^{156}$ Reaves v. Ainsworth, 219 U.S. 296 (1911); Goldstein v. Johnson, 184 F.2d 342 (App.D.C., 1950); Hurley v. Gladman, 47 F.2d 431 (App.D.C., 1931); Nordmann v. Woodring, 28 F. Supp. 573 (Okla., 1939); Reid v. United States, 161 Fed. 469 (S.D.N.Y., 1908), app. dismissed 211 U.S. 529 (1909). However, it has been held that a discharge is reviewable where there is an allegation of a denial of the hearing required by statute. Denby v. Berry, 279 Fed. 317 (App.D.C., 1922). The entire question of judicial review of discharges is discussed in Jones, Jurisdiction of the Federal Courts to Review the Character of Military Administrative Discharges, 57 Col. L. Rev. 917 (1957); Judicial Review of Army Discharge Procedures, 9 Stan. L. Rev. 170 (1956); Judicial Review of Discharge Classifications Determined in Military Administrative Proceedings, 70 Harv. L. Rev. 533 (1957). 


\section{Obligation of Court of Appeals To Consider NARROWER IssUes Not Properdy Presented}

The case of Barr ข. Matteo ${ }^{157}$ represents a unique exercise by the Supreme Court of its supervisory powers over lower federal courts. The suit arose out of an alleged libel by Barr, the Acting Director of Rent Stabilization. The trial court ruled against Barr's claim of an absolute ${ }^{158}$ and a qualified immunity ${ }^{159}$ and the jury returned a verdict for the plaintiffs. When he appealed to the Court of Appeals, Barr abandoned his contention that he was protected by a qualified immunity and argued only that, as Acting Director of Rent Stabilization, he was entitled to absolute immunity. This strategy was prompted by the consideration that a reversal on the absolute immunity contention would result in judgment absolute against the plaintiffs but a reversal on the narrower ground of qualified immunity would lead to a new trial to determine whether Barr had lost the immunity because of malice or lack of reasonable grounds for believing his publication to be true. ${ }^{160} \mathrm{On}$ its own motion the Court of Appeals asked for memoranda discussing whether it could consider the qualified immunity point. That issue, the court held, could not be passed upon because the defendant had not included it in his brief. ${ }^{161}$ The court relied on one of its rules providing that "points not presented according to the rules of the court will be disregarded...." I62 It was then decided that the head of an independent agency such as the Office of Rent Stabilization was not entitled to absolute immunity; judgment for the plaintiffs was accordingly affirmed. ${ }^{163}$

In a three page per curiam opinion the Supreme Court granted certiorari, vacated the judgment, and remanded the case to the Court of Appeals for a decision on the qualified immunity question. ${ }^{164}$ Chief Justice Warren and Justice

157355 U.S. 171 (1957), noted in Supreme Court Will Grant Certiorari To Remand Case for Determination of an Issue Not Properly Raised in the Court of Appeals, $106 \mathrm{U}$. Pa. L. Rev. 1066 (1958).

${ }^{158}$ Absolute immunity affords a complete defense to certain government officials in suits arising out of acts performed within the scope of their authority if the need of society for the free performance of the acts outweighs the desirability of compensating the injured party. Absolute immunity has been extended to the chief executive and his cabinet officers. Whether other officials should be granted the immunity is a matter of sharp dispute. See Absolute Immunity: Too Broad a Protection for the 'Public Interest'?, 10 Stan. L. Rev. 589 (1958); Defamation Immunity for Executive Officers, 20 U. of Chi. L. Rev. 677 (1953).

159 "A ... conditional or qualified privilege is often afforded when absolute immunity is inappropriate. Its protection is much less complete, being contingent upon the defendant's good faith in doing the act complained of." Defamation Immunity for Executive Officers, 20 U. of Chi. L. Rev. 677, 678-79 (1953).

${ }^{160}$ Petition for Certiorari of Aug. 28, 1957, at 7.

161 "A concise statement of the points on which appellant intends to rely, set forth in separate, numbered paragraphs [must be included in each brief.] Each point shall refer to the alleged error upon which appellant intends to rely." Rule 17(c)(7) of the Court of Appeals for the District of Columbia, 28 U.S.C.A. (1952).

162 Rule 17(i) of the Court of Appeals for the District of Columbia, 28 U.S.C.A. (1952). ${ }^{163} 244$ F.2d 767 (App.D.C., 1957).

164355 U.S. 171 (1957). 
Black concurred in the disposition of the case. Justice Brennan voted to grant the petition for certiorari and decide the absolute immunity issue. Justice Douglas argued that certiorari should be denied.

On the surface the Court's opinion seems strange indeed. For the authorities cited $^{165}$ warn courts against deciding issues not properly presented, while the case itself was remanded with instructions to consider just such an issue. On closer examination, though, it appears that the authorities were cited for the proposition that courts should not consider broad issues unless clearly required to do so because there are no narrower grounds for decision. The holding of the Barr case is, therefore, that a procedural rule cannot foreclose disposition of a case on narrow grounds not presented to a court by the litigants. This appears to be a justifiable resolution of the competing considerations. Parties must be required to educate busy courts about the issues for decision and in an advocate system it is not unfair to hold parties to their choice of issues. ${ }^{166}$ Nevertheless, parties must be restrained from forcing a resolution of issues which broad considerations of judicial administration dictate should be left open until a decision is unavoidable. ${ }^{167}$ Those considerations have, for example, made it axiomatic that a constitutional issue be left undecided as long as possible. They cannot be expected to yield to a procedural rule enacted for the convenience of a court. Although holding the procedural rule inapplicable may allow advocates a second chance, the consequent disruption of the appellate process is less than would result from the disposition of cases on unnecessarily broad grounds. If this is true, the implied holding that the Supreme Court may construe the rules of the lower federal courts also seems justifiable. Even though the court of appeals' rule held inapplicable in the Barr decision was enacted pursuant to congressional authorization, ${ }^{168}$ the Supreme Court's action was a necessary employment of its supervisory power over the lower courts.

Although the teaching of the Barr case thus seems ordinary, the case is made unique by the unusual pains which the Court took in making it the vehicle for that lesson. Since only the absolute immunity question was presented, the Supreme Court, in reaching its decision, overrode not only the rule of the court of appeals but also its own maxim that "only the questions set forth in the petition [for certiorari] will be considered by the court."169 Moreover, the deci-

${ }^{165}$ Swift \& Co. v. Hocking Valley Ry. Co., 243 U.S. 281 (1917) (facts contrary to the pleadings stipulated by the parties seeking an advisory opinion); United States v. CIO, 335 U.S. 106 (1948) (refusal to pass upon the constitutionality of a section of the Taft-Hartley Act when the indictment did not charge an offense against the Act); Eccles v. Peoples Bank, 333 U.S. 426 (1948) (the Federal Reserve Board disclaimed any intention to enforce the condition which the plaintiff argued was unconstitutional).

${ }_{166}$ There must, of course, be an exception when considerations of due process so demand. See the discussion of Strauss v. University of New York at note 233 infra.

${ }^{167}$ It is possible for parties to frame the pleadings to present only a broad issue. For example, Barr might have conceded malice; this would have foreclosed any consideration of the qualified immunity issue and left the case to turn on whether Barr had an absolute privilege.

168 " [A]ll courts established by Act of Congress may from time to time prescribe rules for the conduct of their business." 62 Stat. 961 (1948), as amended, 28 U.S.C.A. $\$ 2071$ (1952).

${ }^{169}$ Supreme Court Rule 23 (1) (c), 28 U.S.C.A. (1952). 
sion produced an unusual division of the Court. Justice Frankfurter, the member of the Court most diligent in adhering to procedural limitations, was the senior Justice in the majority. Justice Douglas, who has been less exacting than Justice Frankfurter in procedural matters, ${ }^{170}$ stood alone in dissenting. ${ }^{171}$

The uniqueness of the case is highlighted by the fact that the Supreme Court again granted certiorari ${ }^{172}$ after the court of appeals on remand decided that Barr had a qualified privilege and ordered the district court to hold a new trial. ${ }^{173}$ The petition for certiorari filed on behalf of Barr again presented only the absolute immunity question. The petition was apparently granted so that the Barr case could be heard together with a case from the First Circuit, Lyons v. Howard, ${ }^{174}$ which presented a similar absolute immunity issue. The grant of certiorari in the Howard and Barr cases indicates that the first Barr opinion was not motivated by a desire to avoid a decision of the absolute immunity issue and, simultaneously, to try to annul a broad opinion by the Court of Appeals for the District of Columbia, the tribunal which would decide most of the libel suits against government officials. Instead, the Barr per curiam must have been solely a vehicle for indicating that the Supreme Court may override rules of the lower federal courts in order to prevent the decision of unnecessarily broad issues.

\section{E. Censorship of the Obscene}

For more than a century and a half after the adoption of the First Amendment the constitutional protection of material attacked as obscene remained an open question. ${ }^{175}$ Until 1957 the leading opinions, those by Judges Learned Hand ${ }^{176}$ and Woolsey, ${ }^{177}$ were of lower courts and the issue was barely touched upon in the two Supreme Court cases of Joseph Burstyn, Inc. v. Wilson ${ }^{178}$ and Winters $\%$. New York. ${ }^{179}$ The question was squarely presented in Doubleday v. New York ${ }^{180}$ but there the judgment of the New York Court of Appeals was affirmed per curiam by an equally divided court. In three movie censorship

${ }^{170}$ See, for example, Terminiello v. Chicago, 337 U.S. 1 (1949).

171355 U.S. 171, 173 (1957).

172358 U.S. 917 (1958).

${ }^{173} 256$ F.2d 890 (App.D.C., 1958).

174250 F.2d 912 (C.A.1st, 1958), cert. granted 357 U.S. 903 (1958). It should be noted that the decision of the Court of Appeals and the petition for certiorari were filed after the per curiam opinion in Barr was handed down.

${ }_{175}$ The issue, however, was frequently discussed by commentators. See, e.g., St. JohnStevas, Obscenity and the Law (1956); Symposium, Obscenity and the Arts, 20 Law \& Contemp. Prob., No. 4 (1955); Lockhart and McClure, Literature, the Law of Obscenity and the Constitution, 38 Minn. L. Rev. 295 (1954).

${ }^{176}$ United States v. Kennerly, 209 Fed. 119 (S.D.N.Y., 1913).

177 United States v. One Book Called Ulysses, 5 F.Supp. 182 (S.D.N.Y., 1933).

178343 U.S. 495 (1952).

${ }^{179} 333$ U.S.507 (1948).

${ }^{180} 335$ U.S. 848 (1948). 
cases $^{181}$ which may have involved the issue, the Supreme Court filed enigmatic ${ }^{182}$ per curiam decisions.

In 1957 the Supreme Court resolved the issue by holding in Roth v. United States $^{183}$ that obscene material is not within the constitutional protection of free expression. In addition, the Court put its imprimatur on several tests for determining what material is obscene. The tests, though different at least verbally, all emphasized the same requirements: evaluation of the material as a whole, consideration of the dominant theme, and determination whether there is an appeal to the prurient interests of the average person of the community. Justice Harlan filed a separate opinion drawing a line between federal and state censorship activities. ${ }^{184}$ Chief Justice Warren concurred in the result reached by the Court but expressed reluctance to go beyond the facts presented, namely the deliberate commercialization of smut for smut's sake. ${ }^{185}$ Justices Black and Douglas dissented, protesting a censorship of thoughts. ${ }^{186}$

No full opinion on censorship of obscene material has been produced by the Court since Roth. However, four per curiams involving that issue were handed down during the 1957 term. Mounce v. United States ${ }^{187}$ involved a suit for forfeiture of allegedly obscene magazines seized by the customs service. ${ }^{188}$ The district court and the circuit court of appeals concurred in finding the material obscene. The Supreme Court vacated the judgment below and remanded the case to the district court for reconsideration in light of Roth. This disposition was clearly justified by the lower courts' failure, recognized by the Solicitor General in a confession of error, to apply a proper standard. The courts below had tested obscenity in terms of offense to the community's moral sense rather than appeal to the average person's prurient interests. ${ }^{189}$

In One, Inc. v. Olesen ${ }^{190}$ the publishers of a magazine for homosexuals sued for both a declaratory judgment that a particular issue of the magazine was mailable and an injunction forbidding the postmaster from refusing to accept copies of the issue for mailing. ${ }^{191}$ In Sunshine Book Co. v. Summerfield ${ }^{192}$ the

181 Holmby Productions Inc. v. Vaughn, 350 U.S. 870 (1955); Superior Films v. Dept. of Education and Commercial Pictures Corp. v. Regents of the University of the State of New York, 346 .U.S. 587 (1954); Gelling v. Texas, 343 U.S. 960 (1952).

${ }_{182}$ See, e.g. the perplexity of Fuld, J., in Brown v. Kingsley Books, 1 N.Y.2d 177, 184 n.5 (1956). An analysis of the per curiams is given in Nimmer, The Constitutionality of Official Censorship of Motion Pictures, $25 \mathrm{U}$. of Chi. L. Rev. 625, 629-39 (1958).

183354 U.S. 476 (1957), a combined opinion for Roth v. United States and Alberts v. California.

${ }^{184}$ Id., at $496 . \quad \quad{ }^{188} \mathrm{Id}$ d, at $494 . \quad{ }^{186} \mathrm{Id}$., at 508.

187355 U.S. 180 (1957), vacating 247 F.2d 148 (C.A.9th, 1957).

${ }^{188}$ The service acted pursuant to 46 Stat. 688 (1930), 19 U.S.C.A. \$1305(a) (1937).

${ }^{189}$ See Mounce v. United States, 247 F.2d 148, 149 (C.A.9th, 1957).

${ }^{190} 355$ U.S. 371 (1958), rev'g 241 F.2d 772 (C.A.9th, 1957).

${ }^{191}$ The postmaster relied on regulations based on an inference that 62 Stat. 768 (1948), 18 U.S.C.A. $\$ 1461$ (1950), which provides criminal penalties for mailing obscene matter, grants authority to the Post Office Department to refuse to accept unsealed obscene mail. It should be noted that only the validity of the criminal penalties was upheld in Roth.

192355 U.S. 372 (1958), rev'g 249 F.2d 114 (App.D.C., 1957). 
publisher of a magazine for nudists sued to enjoin the postmaster from refusing to accept certain issues for mailing. ${ }^{193}$ Times Film Corporation v. Chicago ${ }^{194}$ was a suit to enjoin the Chicago Police Commissioner from denying a permit to exhibit an allegedly obscene motion picture. ${ }^{195}$ In each case the lower federal courts found the material obscene and in each case the Supreme Court reversed, citing only the opinion in Roth. ${ }^{196}$ In sharp contrast to the Roth case, the per curiams were unanimous save for the Times Film case where Justices Burton and Clark dissented on the ground that certiorari should not have been granted.

Each of these three cases, One, Inc., Sunshine Book Co., and Times Film, presented far-ranging constitutional issues not resolved by Roth. In One, Inc. the applicability of the Roth standards to homosexual literature was called into question. If taken literally, those standards-emphasizing appeal to the prurient interests of the average person of the community-would eliminate all homosexual material from the category of the obscene. In both One, Inc. and Sunshine Book Co. the Court was faced with the refusal of postal officials to receive magazines for mailing, a de facto censorship the effectiveness of which is insured by the dependence of magazines on special mailing privileges. In the Times Film case the constitutionality of movie censorship was called into question. Each case presented the issue whether a prior restraint on obscenity is permissible. In view of the administrative nature of the censors this issue was not foreclosed by Kingsley Books, Inc. v. Brown $n^{197}$ where the Court upheld prior restraints imposed by courts acting under special safeguards.

It is difficult to determine whether the Court reached and decided these issues. Although it seems unlikely that novel issues of such magnitude would be silently decided, a not implausible argument can be made that the field of censorship of the obscene is a delicate and embarrassing one in which careful analysis, to the extent to which it is possible, frequently produces more confusion than it dispels. Consequently, the argument would run, the Court might very sensibly decide important issues per curiam. On the other hand, since the field does contain so many traps, the Court might well believe that the legal profession deserves at least the enlightenment which would be fostered by a full opinion. A more persuasive argument is that it is extremely unlikely that the far-reaching issues presented would have been unanimously resolved.

By an examination of the narrow issues presented by each case, it is possible to show that the Court could have reversed without deciding the broad consti-

${ }^{193}$ See note 191 supra.

194355 U.S. 35 (1957), rev'g 244 F.2d 432 (C.A.7th, 1957).

${ }^{195}$ The Municipal Code of Chicago requires that no movie may be shown without an exhibition permit issued by the Chicago Police Commissioner. A permit may be refused for obscene movies.

196 The opinion in Roth was filed for both Roth v. United States and Alberts v. California. The former involved federal, the latter state action. Each of the per curiam cases except one involved federal censorship and the citation was to Roth. The Times Film case involved state suppression and Alberts was cited.

297354 U.S. 436 (1957). 
tutional questions. In One, Inc. reversal could have been predicated on the error of the lower courts in weighing the impact of the magazine not upon l'homme moyen sensuel but rather upon persons unusually susceptible to perverse stimulation. ${ }^{198}$ It is less easy to discern the Court's basis for reversal in the Sunshine Book Co. and Times Film cases. In those cases the standards set forth by the lower courts were consistent with the Roth requirements. However, in the Sunshine Book Co. case there was considerable dissension in the court of appeals on whether the magazines had been judged as a whole. ${ }^{199}$ This question of proper application may have been the one on which the Supreme Court based its reversal. In the Times Film case the absence of any indication in the record that an approved test had not been applied suggests that the Court dealt with still another question, whether the determination of obscenity was correct. This interpretation of the Times Film decision is supported by the fact that Justices Clark and Burton, who have frequently argued against overruling the evaluation of facts made by lower courts, ${ }^{200}$ noted their objection to granting certiorari. The absence of similar objections in the other per curiam obscenity cases is easily understood. For in Mounce the Court remanded the case to the district court for a new determination of the issue of obscenity. The definitive reevaluation made by the Court in Sunshine Book Co. and One, Inc., implicit in the fact that the Court reversed rather than vacated and remanded, may not have been objectionable to Justices Burton and Clark since other issues were decided and the reevaluation had the virtue of ending the litigation.

The pattern thus formed by the per curiams indicates that courts may commit three errors in determining obscenity. An improper standard may be adopted, a correct standard may be faultily applied, and an improper result may be reached although an approved test is applied. But regardless of which error is involved, the Supreme Court may redetermine whether the material is obscene. Only in Mounce was the case remanded for reconsideration; this exception is explained by the fact that in that case alone did the Court lack the opportunity to view the allegedly obscene matter. ${ }^{201}$

Determination that the material involved in the three per curiams besides Mounce was not obscene would not have been difficult if the Courts interprets Roth as establishing a rule that only hard-core, dirt-for-dirt's sake pornography is obscene. This interpretation is supported by the argument that the high status accorded free expression by the Court requires a very narrow construction of any category which, - like obscenity, is considered unprotected by the First Amendment. However, Mr. Justice Harlan's opinion in Roth indicates

${ }^{198}$ One, Inc. v. Olesen, 241 F.2d 772, 778 (C.A.9th, 1957).

199 Originally the court of appeals, with only three judges sitting, split 2-1 for reversal of the finding of obscenity. This opinion is unreported but is printed in the Petition for a Writ of Certiorari at 62 . On rehearing the court, sitting en banc, split five for affirmance, three for reversal. See 249 F.2d 114 (App. D.C., 1957).

${ }^{200}$ See, e.g., their dissent in Jones v. United States, 357 U.S. 493, 500 (1958).

${ }^{201}$ Correspondence on file at the offices of the University of Chicago Law Review from the attorneys involved in the One, Inc., Sunshine Book Co., and Times Film cases and from the Clerk, Court of Appeals for the Ninth Circuit. 
that the Court there approved suppression of obscene material which would not universally be considered hard-core pornography. ${ }^{202}$

Regardless of the definition of obscenity adopted, it may be questioned whether the Supreme Court should sit as the "High Court of Obscenity,"203 to use Mr. Justice Jackson's words. When, as in each of the per curiam cases, the original determination of obscenity is made by a judge rather than a jury, Federal Rule 52(a), ${ }^{204}$ if applicable, forbids setting aside findings which are not "clearly erroneous." It may be suspected that the Court is not strictly following Rule 52(a) in obscenity cases. In the Times Film case, for example, both the district judge and a unanimous three-judge bench of the court of appeals found the movie obscene; yet the Supreme Court may have overruled this finding. Nevertheless, the determination of obscenity blends fact and constitutional issues. Upon that determination turns the protection of the First Amendment. This blending, coupled with the fact that the sole relevant exhibit-the allegedly obscene material-may be as well evaluated by the Supreme Court as by lower tribunals, renders it difficult to question the propriety of de novo determinations by the Supreme Court.

\section{F. State TaXation ${ }^{205}$-Liguor Control}

Gordon v. Texas ${ }^{206}$ may represent an expansion of the Twenty-first Amendment. ${ }^{207}$ Gordon had attempted to transport eleven fifths of rum from Mexico through Texas to his home in North Carolina. His refusal to pay the Texas liquor tax resulted in his conviction for violating the Texas Liquor Control Act. ${ }^{208}$ On appeal to the Texas Court of Criminal Appeals, ${ }^{209}$ the conviction was sustained over Gordon's contention that the statute, as applied to his car-

202354 U.S. 476, 508 (1957).

${ }^{203}$ During the course of the oral argument in Doubleday \& Co. v. New York, 335 U.S. 848 (1948), MIr. Justice Jackson inquired, "Does your argument mean that we would have to take every obscenity case and decide the constitutional issues on the merits of the literary work? It seems to me that would mean we would become the High Court of Obscenity." 17 U.S. Law Week 3119 (194S).

${ }^{204}$ Fed. Rules Civ. Proc. 52(a): "In all actions tried upon the facts without a jury... [f]indings of fact shall not be set aside unless clearly erroneous."

205 Two per curiams, United States v. Vorreiter, 355 U.S. 15 (1957), and United States v. R. F. Ball Constr. Co., 355 U.S. 587 (1958), appear to substantially alter the law of federal tax liens. These per curiams are discussed in Brown, Foreword to the Supreme Court, 1957 Term, 72 Harv. L. Rev, 77, 86-87 (1958) and Plumb, Federal Tax Collection and Lien Problems (Second Installment), 13 Tax L. Rev. 459, 475 (1958). .

206355 U.S. 369 (1958).

207 The relevant portion of the Amendment reads: "The transportation or importation into any State, Territory, or possession of the United States for delivery or use therein of intoxicating liquors, in violation of the laws thereof, is hereby prohibited." U.S. Const. Amend. 21, Sec. 2.

${ }^{208}$ The Act imposes a tax on the first possession of any liquor brought into Texas. It makes illegal the possession of any alcoholic beverage on which the tax has not been paid. Texas Penal Code (Vernon's, 1948) Art. 666.

${ }^{209} 310$ S.W.2d 328 (Tex. Crim. App., 1956). 
riage of liquor through Texas, violated the Import-Export ${ }^{210}$ and Commerce ${ }^{211}$ Clauses. The Supreme Court affirmed the conviction, citing only the Twentyfirst Amendment and Carter v. Virginia. ${ }^{212}$

From these citations little can be gleaned about the grounds of affirmance. It is not clear what bearing the citations have on Gordon's contention that the Import-Export Clause shielded him from the Texas levy. The Carter case in no way involved importations and probably was cited only as an answer to the Commerce Clause argument. Citation of the Twenty-first Amendment may have been intended to indicate that the Amendment excludes liquor from the protection of the Import-Export Clause. However, the impact of the Amendment on that clause has never been discussed in any reported case and it is at least open to doubt whether the Amendment confers upon the states powers which might conflict with the nation's foreign policy. But since the ImportExport Clause argument could justifiably have been tacitly rejected on the ground that the Texas tax was imposed on the possession rather than the importation of liquor, ${ }^{213}$ it is possible that the Court may have intended to cite the Amendment only in answer to the Commerce Clause contention.

Even if such were the Court's intention, it is still difficult to determine the precise holding of the case. The Twenty-first Amendment by its terms applies only to "transportation or importation" into a state for "delivery or use therein." The Supreme Court has never answered the question whether the quoted language embraces transportation, like that in the Gordon case, through a state. ${ }^{214}$ The question was carefully avoided in Carter v. Virginia. ${ }^{215} \mathrm{An}$ affirmative answer would have removed any restrictions imposed by the Commerce

210 'No state shall, without the Consent of the Congress, lay any Imposts or Duties on Imports and Exports, except that which may be absolutely necessary for executing its inspection Laws; and the net Produce of all Duties and Imposts, laid by any State on Imports and Exports, shall be for the Use of the Treasury of the United States; and all such Laws shall be subject to the Revision and Control of the Congress." U.S. Const. Art. 1, Sec. 10, cl. 2.

211 "The Congress shall have Power ... to regulate Commerce with foreign Nations, and among the several States and with the Indian Tribes." U.S. Const. Art. 1, Sec. 8, cl. 3.

212321 U.S. 131 (1944).

${ }^{213} \mathrm{By}$ its terms the statute levies the tax upon "the first sale, possession, distribution, or use" in Texas. Gordon claimed the levy was an import tax because stations to inspect for liquor were set up only on the Mexican border. However, Texas could reasonably have concluded that those stations were the only ones which justified the expense of maintaining them. Moreover, the tax actually was assessed on incoming liquor regardless of its origin. See, e.g., Boles v. State, 132 S.W.2d 881 (Tex. Crim. App., 1939).

214 The question has been directly passed on in only one reported case. The Supreme Court of Virginia held in Williams v. Commonwealth, 169 Va. 857,192 S.E. 795 (1937), that the Amendment does not apply to through liquor traffic.

${ }^{215}$ In the Carter case, Virginia's requirement of a bond, bill of lading showing the route to be travelled, and use of the most direct route were held not to violate the Commerce Clause. The Court stated that "[i]n the present case we need not consider the power of Virginia under the Trenty-first Amendment to regulate through shipments." Carter v. Virginia, 321 U.S. 131,137 (1944). 
Clause on state regulation of through liquor traffic. ${ }^{216}$ The Carter decision preserved limits on state power by holding that the Commerce Clause is not infringed by strict but reasonable regulations. This holding could have been used as the sole basis for disposing of the Gordon case. ${ }^{217}$ However, the fact that the Texas laws were somewhat less reasonable than those of Virginia ${ }^{218}$ may have impelled the Court to rest the case on the Twenty-first Amendment rather than the Carter rationale. If so, it is difficult to explain the citation of the Carter case. It is possible that the citation was an oblique adoption of Justice Frankfurter's concurring opinion in Carter ${ }^{219}$ In that opinion Justice Frankfurter argued that "delivery" as used in the Amendment includes through transportation ${ }^{220}$ and that the Amendment grants a state the power not only to prohibit importation for use in the state but also to enforce that prohibition by controlling through liquor traffic. The triumph of Justice Frankfurter's position seemingly is the only basis for explaining the concomitant citation of Carter and the Twenty-first Amendment. However, until the Court makes it clear whether this interpretation is correct, the Gordon case will stand as an enigmatic addition to a long line of cases allowing states to impose rigorous limitations on liquor traffic.

\section{G. Judicial Review of Municipal Annexations}

Citing no authorities, the Supreme Court dismissed for want of a substantial federal question the case of Texas ex rel. Pan American Production Co. v. Texas City. ${ }^{21}$ Pan American, the owner of mineral leases on submerged tidelands, had sued to set aside a municipal ordinance annexing the land and to enjoin the city from enforcing the ordinance. It was argued that because the annexation

${ }^{216}$ It has been held that the right of a state to prohibit or regulate the importation of intoxicating liquor is not limited by the Commerce Clause. State Board v. Young's Market Co., 299 U.S. 59 (1936).

${ }^{217}$ Texas might have argued that its statute merely established a presumption that liquor transported into Texas was for consumption in that state. The possibility that the Court could have relied on this interpretation as a ground for finding the statute reasonable is foreclosed by the fact that Texas stipulated that the liquor Gordon carried was for consumption only in North Carolina.

${ }^{218}$ It appears that the Texas statute had no purpose other than raising revenue. In contrast, the Virginia statute seemingly was designed to protect the elaborate state-controlled distribution system. See Va. Code (Michie, 1942) c. 184A. That system would have been disrupted by diversion of through liquor traffic into local bootleg sales.

${ }^{219}$ Carter v. Virginia, 321 U.S. 131, 139 (1944).

220 "Since we are dealing with a constitutional amendment that should be broadly and colloquially interpreted, liquor that enters a State in the manner in which the liquor here came into Virginia may, without undue liberty with the English language, be deemed to be for 'delivery' there even though it is consigned for another State. The Twenty-first Amendment prohibits the 'transportation or importation into any State . . of intoxicating liquors, in violation of the laws thereof,' not when the liquor is for delivery and use but for 'delivery or use therein.' In other words, liquor need not be intended for consumption in a State to be deemed to be imported into the State and therefore subject to control by that State." Id., at 140-41. (Italics in original.)

221355 U.S. 603 (1958). 
bore no reasonable relation to the needs of the city and because no benefit could accrue to Pan American, the annexation and the resulting taxation constituted a taking of property in violation of the Fourteenth Amendment. The Texas trial court held for the city on the ground that the annexation was a political matter not subject to judicial review. ${ }^{222}$ The Court of Civil Appeals affirmed the judgment, ${ }^{223}$ saying that the annexation could be judicially reviewed but would not be set aside since Pan American had failed to sustain the burden of proving beyond a reasonable doubt that the city's action was arbitrary. The Texas Supreme Court rejected the position taken by the Court of Civil Appeals but nevertheless affirmed the judgment, ${ }^{224}$ citing a number of its previous opinions for the proposition that a municipal annexation is a political question unreviewable even upon a showing of palpable arbitrariness.

Summary dismissal leaves in doubt the Supreme Court's position on municipal annexations. The Court, ignoring the rationale of the trial and supreme courts of Texas, may have decided simply that even if municipal annexations are judicially reviewable, Pan American did not make a sufficient showing of arbitrariness. Or the Court may have intended to indicate that municipal annexations are unreviewable. However, although the commentators, ${ }^{225}$ most of the state courts, ${ }^{226}$ and much language in early Supreme Court opinions ${ }^{227}$ state that annexation is a political question, the contrary position is not without wellreasoned support. ${ }^{228}$ Even in the Supreme Court, claims of arbitrariness have not gone unheeded..$^{229}$ Moreover, there is a line of cases dealing with the creation of special purpose districts in which the Court has held that the ordinances creating the districts would be subject to review upon a claim of palpable arbitrariness or abuse of power. ${ }^{230}$ In the Pan American case the Court was urged to compare for the first time the reasoning of the special purpose district cases and the annexation cases. It may be argued that the two types of cases

${ }^{222}$ The unreported opinion is printed in the Brief for Appellant at A-1.

${ }^{223}$ The unreported opinion is printed in the Brief for Appellant at A-19.

224 157 Tex. 000, 303 S.W.2d 780 (1957).

2251 Dillon, Municipal Corporations $\$ \S 58,355$ (5th ed., 1911); 2 McQuillin, Municipal Corporations $\$ 7.10$ (3d ed., 1949).

${ }^{226}$ The cases are reviewed in 64 A.L.R. 1335 (1929).

${ }_{227}$ Hunter v. Pittsburgh, 207 U.S. 161 (1907); Clark v. Kansas City, 176 U.S. 114 (1900); Kelly v. Pittsburgh, 104 U.S. 78 (1881); Mount Pleasant v. Beckwith, 100 U.S. 514 (1879); Commissioners of Laramie County v. Commissioners of Albany County, 92 U.S. 307 (1875); Clay v. Eustis. 7 F.2d 141 (S.D.Fla., 1925), appeal dismissed 273 U.S. 781 (1926).

${ }^{228}$ Chesapeake \& O. Ry. Co. v. Silver Grove, 249 S.W.2d 520 (Ky. Ct. of App., 1952); Florida ex rel. Davis v. Stuart, 97 Fla. 69, 120 So. 335 (1929); Municipal Corporations-Constitutional Law-Annexation by Municipal Corporation of Submerged Adjacent Lands Valid against Due Process of Law Objections, 36 Tex. L. Rev. 113 (1957).

${ }^{229}$ Clark v. Kansas City, 176 U.S. 114, 121 (1900); Bradley, J., concurring in Davidson v. New Orleans, 96 U.S. 97, 107 (1877). Even in Kelly v. Pittsburgh, 104 U.S. 78 (1881), often cited for its political question language, the Court did not consider the annexation to be one in which no benefit would be conferred by the municipality.

${ }^{230}$ E.g., Houck v. Little River District, 239 U.S. 254 (1915); Myles Salt Co. v. Iberia Drainage District, 239 U.S. 478 (1916). 
cannot logically be distinguished. ${ }^{231}$ The only possible grounds on which to base a distinction are that a city, but not a special purpose district, can always provide a taxpayer with some benefits, ${ }^{232}$ and that a city not only provides services but, in addition, is the unit which has been chosen to govern. These grounds, however, give such little deference to elemental notions of fairness, particularly in a case like Pan American which involved only submerged wasteland, that it seems unwise to rely on them without explicit justification.

\section{H. DUe Process: UneXpected Legislative ACTION AND AN APPELLANT'S RIGHTS}

The Court also dismissed for lack of a substantial federal question Strauss v. University of New York ${ }^{233}$ in which a group of five optometrists, acting on behalf of themselves and others similarly situated, sued for a declaratory judgment and for injunctive relief from a regulation of the Commissioner of Education governing the size, number, and degree of illumination of advertising signs. ${ }^{234}$ The optometrists argued before the lower New York courts that the regulation was unreasonable, that it was discriminatory because it did not apply to professions in economic competition with optometrists, and that it was unduly broad because it proscribed even the use of an illuminated sign containing an optometrist's name and profession. In presenting their case before the New York Court of Appeals the optometrists relied almost wholly on the third objection. After oral argument and submission of the briefs in the case the regulation was amended to allow optometrists to use illuminated signs containing their names and profession. ${ }^{235}$ The Court of Appeals upheld the amended version of the regulation in a very brief opinion. ${ }^{236} \mathrm{~A}$ motion for rehearing was summarily denied. ${ }^{237}$

The optometrists appealed to the Supreme Court contending that the failure of the New York Court of Appeals to allow them to present their case against the amended regulation deprived them of their day in court in violation of the Fourteenth Amendment. They relied upon Saunders v. Shaw ${ }^{238}$ which held that a state supreme court violated the Fourteenth Amendment by rendering judgment absolute against a party without providing an opportunity to controvert

231 The argument has been made in Florida ex rel. Davis v. Stuart, 97 Fla. 69, 120 So. 335 (1929); see also the dissent in the Pan American case, 157 Tex. 000, 000, 303 S.W.2d 780, 786 (1957).

${ }^{232}$ Brief for Appellee at 16-17. ${ }^{233} 355$ U.S. 394 (1958).

${ }^{234}$ The regulation forbade "advertising by means of large display, glaring, illuminated or flickering signs...." Art. VIII, Sec. 70, Regulations of the Commissioner of Education of New York.

${ }^{235}$ The amendment read: "Nothing herein contained shall be deemed to prevent the illumination of a sign setting forth the name of the practitioner and the word 'optometrist' provided that the illumination is not colored and such sign does not otherwise confict with this regulation."

${ }^{235} 2$ N.Y.2d 464, 141 N.E.2d 595 (1957), aff'g 2 A.D.2d 179, 153 N.Y.S. 2 d 397 (1956).

${ }^{237}$ Jurisdictional Statement for Appellants at 5a.

${ }^{238} 244$ U.S. 317 (1917). 
facts held inadmissible by the trial court but found controlling by the supreme court. The dismissal of Strauss might, on the one hand, be justified upon the view that the substantive merits of the plaintiffs' claim were so negligible that, in spite of possible harm, the case did not merit the Court's attention. On the other hand, it is possible that by dismissing the case the Court held in effect that it cannot reasonably be contended that the Saunders doctrine is applicable to the Strauss facts.

Such a holding would not be indefensible. In Strauss the amendment of the regulation, rather than introducing a new and unexpected issue, constituted a concession to the optometrist' strongest argument. It cannot be contended that the plaintiffs did not have their day in court on new matter suddenly injected into the case. However, it may plausibly be argued that Strauss presented the same problem as Saunders in an inverted form. In the latter case an unanticipated issue appeared late in the proceedings; in the former the major issue was suddenly removed, leaving the case to turn upon what had previously been thought to be inconsequential points. Although it may be argued that the Due Process Clause is not designed to protect afterthoughts and that parties consequently should present their full arsenal of arguments, the more persuasive position appears to be that the Strauss case is basically indistinguishable from Saunders. In the latter case a rule of evidence excluded a certain issue in order that there would be a more rational trial. In Strauss issues were excluded by the necessity for a rational appellate procedure. Cases can be decided more efficiently if counsel are allowed to structure their arguments to focus attention upon their strongest and most appealing points. The energy of the court system is thereby conserved. Unless opportunity be given to adjust to unexpected changes at either the trial or appellate level, the courts cannot possibly be adequately informed about the merits of cases. ${ }^{239}$ Thus the optometrists presented a plausible and novel due process argument which may well have deserved more extended treatment than summary dismissal.

\section{State Crmminal Cases}

\section{AUTHORITX TO DETERMINE SANTTY OF CONDEMINED PRISONER}

It has long been recognized that due process does not require that a condemned prisoner who asserts supervening insanity be given a full judicial proceeding to adjudicate his claim..$^{240}$ It was not until 1950, ${ }^{241}$ however, that the

${ }^{239}$ This view seems to be supported by the fact that the Court of Appeals did not even consider the claim that the regulation was discriminatory and gave only the briefest treatment to the claim of unreasonableness; it may well be that the Court of Appeals was not familiar with the plaintiffs-appellants' arguments on these points.

${ }^{240}$ If such proceedings were required 'sit would be wholly at the will of a convict to suffer any punishment whatever, for the necessity of his doing so would depend solely upon his fecundity in making suggestion after suggestion of insanity, to be followed by trial upon trial." Nobles v. Georgia, 168 U.S. 398, 405-06 (1897). The question of whether a state could constitutionally execute insane condemned prisoners has never been before the Supreme Court. All the states, however, seem to follow the common-law rule forbidding such executions. For state statutes see Justice Frankfurter's dissent in Solesbee v. Balkcom, 339 U.S. 9, 14 and Appendix (1950). 
Supreme Court held, in Solesbee v. Balkcom, ${ }^{242}$ that due process is satisfied by a statute vesting in a governor the authority to make an unreviewable ex parte determination of a prisoner's sanity. In the 1957 term, the Solesbee case was used as the sole authority in the summary per curiam opinion in Caritativo v. Californi $^{243}$ which upheld a California procedure giving to the prison warden the power to make an ex parte determination of sanity. ${ }^{244}$ Justice Harlan, feeling uncertain about the implications of Solesbee, concurred in an opinion detailing his reasons for believing the California procedure was compatible with due process. Justice Frankfurter, joined by Justices Brennan and Douglas, dissented, arguing that the Court was extending the very questionable doctrine of Solesbee.

The Caritativo case undeniably extends the Solesbee holding, which emphasized the special aptness of the state's highest executive to bear the "solemn responsibility"245 of determining sanity, to cover a procedure vesting authority in an official subordinate to the governor. The Court may well have considered such an extension to be the only significant factor involved in disposing of Caritativo. The dissent indicates that the extension to wardens is the only change effectuated by the decision. Moreover, the majority's citation of Solesbee included a specific page reference, ${ }^{248}$ apparently indicating reliance on the declaration that the power of executive clemency, to which the power to stay the execution of insane convicts was assimilated, had often been delegated by chief executives to lesser officials. If application of the Solesbee doctrine to a procedure granting authority to a warden were a sufficient basis for disposing of the case, summary disposition seems sensible. For the warden is, as Justice Harlan pointed out, "the official who beyond all others has had the most intimate relations with, and best opportunity to observe, the prisoner."247

However, Caritativo differs from Solesbee in other significant ways. In Caritativo the warden refused to hear any evidence of insanity offered. ${ }^{248}$ In Solesbee not only was there no evidence of such a refusal, but the Court expressly presumed that most authorities would welcome any information presented by the condemned. ${ }^{249}$ On the other hand, whereas the use of medical advice was discretionary in the Georgia procedure approved in Solesbee, ${ }^{250}$ the California statute provides a greater safeguard by requiring psychiatric examinations of the prisoner. ${ }^{251}$

It is possible that the Court considered these differences in statutory re-

241 The question arose in Phyle v. Duffy, 334 U.S. 431 (1948), but was not decided; the case was sent back upon the suggestion of the state attorney general that the petitioner had not exhausted his state remedies.
242339 U.S. 9 (1950).
${ }^{247} 357$ U.S. 549, 551 (1958).
${ }^{243} 357$ U.S. 549 (1958).
${ }^{243} \mathrm{Id}$., at 550.
${ }^{244}$ Calif. Penal Code (Deering, 1949) \$3701.
${ }^{249} 339$ U.S. 9,13 (1949).
245339 U.S. 9,13 (1950).
$250 \mathrm{Ga}$. Code Ann. (1955) \$27-2602.
${ }^{246} \mathrm{Id}$., at 12.
251 Calif. Penal Code (Derring, 1949) \$3701. 
quirements constitutionally insignificant or that, taken together, the defects and merits balanced out so that the California procedure was substantially the same as that of Georgia. Perhaps the lack of notice paid to these elements indicates that any reasonable procedure, without regard to who exercises the discretion and on what grounds that discretion is exercised, will be considered to accord with due process. If Caritativo stands for such a principle of reasonableness then that case would constitute a substantial extension of the circumspect doctrine set forth in Solesbee.

\section{PROSECUTORS: REPRESENTATIVES OF JUSTICE OR ADVOCATES?}

Relying on the frequently applied doctrine of Mooney v. Holohan, ${ }^{252}$ the Supreme Court in a per curiam opinion upset the conviction in Alcorta v. Texas. ${ }^{253}$ Alcorta admitted killing his wife when he came upon her in a parked car with Castilleja, the only eyewitness to the crime, but he contended that the killing came within the Texas "murder without malice" statute. ${ }^{254} \mathrm{He}$ claimed that he had found his wife and Castilleja kissing and that the slaying was the result of a sudden passion arising from an adequate cause. Alcorta did not know, either at the time of the killing or at the trial, that Castilleja had had sexual intercourse with the deceased on five or six occasions. Although the prosecutor knew of Castilleja's intimacy with the deceased, he did not offer the information to the defendant nor did he reveal it to the jury. Castilleja was instructed to disclose the information only if asked about it by the defense. Moreover, during the trial the prosecutor asked Castilleja a series of ambiguous questions regarding his prior relationship with the deceased; ${ }^{255}$ the questions were apparently fashioned so that Castilleja could answer them without revealing any information about his illicit affair. Alcorta was unable to convince the jury that the slaying was without malice and he was sentenced to death.

When he learned about the prosecutor's tactics, Alcorta petitioned the trial court for a writ of habeas corpus on the ground that he had been deprived of a fair trial in violation of both the state and federal constitutions. The petition was denied and the Texas Court of Criminal Appeals affirmed the denial. ${ }^{256}$ The U.S. Supreme Court granted certiorari and reversed. The Court, in a rather extended opinion for a per curiam disposition, found that the prosecutor's questioning had "elicited" testimony which taken as a whole "tended" to impeach Alcorta's claim of adequate cause which, but for Castilleja's testimony, "might" have been believed. ${ }^{257}$ The prosecutor's tactics, the Court held, constituted a denial of due process under the doctrine of Mooney v. Holohan. ${ }^{258}$ That doctrine is that "Due Process is a requirement that cannot be deemed to be

252294 U.S. 103 (1935); the Court in the Alcorta case also cited Pyle v. Kansas, 317 U.S. 213 (1942), which merely reiterates the Mooney rule.

253355 U.S. 28 (1957).

${ }^{254}$ This is a voluntary manslaughter statute. Texas Penal Code (Vernon's, 1948) Arts. 1257(a), (b), (c).

${ }_{255} 355$ U.S. 28, 30 (1957).

257355 U.S. 28,31 (1957).

${ }^{256} 294$ S.W.2d 112 (Tex. Crim. App., 1956).

258294 U.S. 103 (1935). 
satisfied by mere notice and hearing if a state has contrived a conviction through the pretense of a trial which in truth is but used as a means of depriving a defendant of liberty through a deliberate deception of court and jury by the presentation of testimony known to be perjured." ${ }^{259}$ Although only dictum, ${ }^{260}$ this principle has been relied upon in numerous cases. ${ }^{261}$ But even if it is conceded that the prosecutor's tactics in the Alcorta case were somewhat questionable, that decision goes significantly farther than any of the prior cases in finding fundamental unfairness.

In those of the prior cases which involved perjury, the witnesses, urged on by prosecutors, told stories which were patently false and which directly led to the conviction of the defendant. ${ }^{262}$ At worst, it could be said that Castilleja told only a half truth; even the Court asserted merely that he "tended" to give the jury a "false impression" about facts which "might" have been relevant. ${ }^{263}$ Moreover, the prior cases are replete with allegations that prosecutors deliberately induced perjured testimony by threats, ${ }^{264}$ bribes, ${ }^{265}$ or promises of illegal benefits. ${ }^{266}$ No such allegations were made in Alcorta.

In addition, the cases dealing with suppression of evidence concerned facts or objects exclusively within the state's control. ${ }^{267}$ The defense in Alcorta could easily have questioned Castilleja in regard to his previous relationship with the deceased either on cross-examination or at a pretrial hearing. ${ }^{268}$

Finally, and this is perhaps the crucial point, the previous cases all contained

${ }^{259} \mathrm{Id}$., at 112. The defendant had claimed that the sole ground for conviction was perjured testimony knowingly used and that the defendant could not by reasonable diligence have discovered before the trial the evidence which proved the existence of perjury.

${ }^{260}$ A motion for leave to file a petition for a writ of habeas corpus was denied on the exclusive ground that petitioner had not exhausted his state remedies. The Court, disclaiming any intention of dealing with the due process question at length, merely answered the suggestion of the state attorney general that only procedural due process questions could be raised.

${ }^{261}$ The cases cited below for comparison with Alcorta are not all the cases dealing with partisan acts by prosecutors but are merely representative decisions.

${ }^{252}$ Bales v. Lainson, 244 F.2d 495 (C.A.8th, 1957) (witness testified that the prosecutor hounded him night and day to get him to swear that defendant committed a crime which the witness knew the defendant had not committed); Montgomery v. Ragen, 86 F.Supp. 382 (N.D. Ill., 1949) (prosecutrix testified that the defendant had raped her when in fact he had not).

${ }^{263}$ The fact of prior intercourse by no means proves that they were embracing when Alcorta discovered them; even if they were embracing, Alcorta may not have acted in a sudden heat of passion. Evidence was produced at the trial that Alcorta had borrowed the murder weapon the day before the killing and had told friends that he was going to leave town shortly. 1949).

${ }^{264}$ Pyle v. Kansas, 317 U.S. 213 (1942); Montgomery v. Ragen, 86 F.Supp. 382 (N.D. Ill.,

265 White v. Ragen, 324 U.S. 760 (1945).

${ }^{266}$ Bales v. Lainson, 244 F.2d 495 (C.A.8th, 1957).

${ }^{267}$ Almeida v. Baldi, 195 F.2d 815 (C.A.3d, 1952) (murder bullet discovered and suppressed by prosecution); Thompson v. Dye, 221 F.2d 763 (C.A.3d, 1955) (failure to call policemen whom the prosecutor knew would testify defendant was drunk although a policeman was called who testified the defendant was sober).

${ }^{268}$ See Texas Code of Crim. Proc. (Vernon's, 1954), Arts. 245, 250. 
undeniable evidence of bad faith on the part of the prosecutor. ${ }^{269}$ Here the prosecutor might argue that he sincerely disbelieved Alcorta's story ${ }^{270}$ and did not wish to weaken the state's case by coming forth with the facts of the previous relationship between the deceased and Castilleja, knowing that his inaction did not foreclose Alcorta from opening up the issue. He could, moreover, argue that the questions he put to Castilleja, viewed in the context of the entire testimony, by no means necessarily indicated an intent to deceive or mislead.

The prosecutor might buttress his good faith argument by the cases in which defendants claimed fundamental unfairness because the state failed to call witnesses who might have told stories favorable to the defense. ${ }^{271}$ In the vast majority of these cases the courts were quite sympathetic to prosecution tactics, apparently feeling that the prosecutor should be viewed as an advocate and given freedom to pursue and elaborate his own theory of the case and to exercise iudgment in calling witnesses and raising questions in the mind of the jury.

Tt seems clear from the forgoing comparisons that the alleged abuses by the prosecutor in Alcorta were considerably milder than those appearing in previous cases. Perhaps it is because the abuses in the prior cases were so flagrant that the broad language of Mooney served as a sufficient guide. The ambiguity presented by Alcoria, however, seems to call for some clarification of the principle upon which a determination of bad faith is to be made. Whether the prosecutor is to be viewed as entitled to the freedom and discretion of an advocate, as some courts have suggested, ${ }^{272}$ or is to be viewed as an impartial representative of public justice whose interest in a criminal prosecution is not that the state shall win a case, but that justice shall be done, as other courts have indicated, ${ }^{273}$ would seem to control the determination of good faith in an ambiguous case such as Alcorta. A holding that the actions of the prosecutor in Alcorta constitute fundamental unfairness would indicate that the Court is rejecting, in large part, the advocate theory in favor of the representative of justice theory.

\section{INDIGENTS' RIGHTS ON APPEAL}

In Griffin v. Illinois ${ }^{274}$ the Supreme Court held that where a state provides appellate review for all convicted defendants, but requires a stenographic transcript to perfect an appeal, it is a denial of constitutional rights guaranteed

${ }^{269}$ Cases cited notes 264-267 supra.

${ }^{270}$ In spite of subsequent admissions about intercourse with Alcorta's wife, Castilleja never admitted they they were embracing on the night of the murder. See also note 263 supra.

271 E.g., Griffin v. United States, 183 F.2d 990 (App. D.C., 1950) (dissent); Curtis v. Rives, 123 F.2d 936 (App. D.C., 1941); Williams v. United States, 20 F.2d 269 (App. D.C., 1927). Contra: Thompson v. Dye, 221 F.2d 763 (C.A.3d, 1955), where there was a failure to call witnesses in addition to a clearly misleading statement by the prosecutor. How ever, a concurring judge cautioned that the case should be limited to its facts. Id., at 768.

272 E.g., Curtis v. Rives, 123 F.2d 936 (App. D.C., 1941); Williams v. United States, 20 F.2d 269 (App. D.C., 1927); Pike v. State, 103 Fla. 594, 139 So. 196 (1931).

${ }^{273}$ Berger v. United States, 295 U.S. 78 (1935); Griffin v. United States, 183 F.2d 990 (App. D.C., 1950); Canon 5, A.B.A. Canons of Professional and Judicial Ethics (1957).

${ }^{274} 351$ U.S. 12 (1955). 
by the Fourteenth Amendment not to provide indigent defendants with a free transcript or its equivalent so that they could get "as adequate appellate review" as those who could afford to purchase a transcript. The Griffin opinion left unanswered several questions: (1) will the Griffin doctrine be applied retroactively; (2) will the states be allowed any means to protect themselves against frivolous appeals; (3) does the phrase "as adequate appellate review" require that the state give free to the indigent precisely the same things which the affluent prisoner would purchase, or only a substantial equivalent?

Eskridge v. Washington Prison Board ${ }^{275}$ and Ross v. Schneckcloth, 276 the first cases involving the problem of post-conviction appeal decided by the Supreme Court subsequent to Griffin, appear to shed some light on these questions. ${ }^{277}$ Eskridge, who had been convicted prior to the time Griffin was decided, made a timely appeal and simultaneously applied for a free transcript under a Washington statute which provided that the trial judge may order a transcript to be given if in his opinion "justice will thereby be promoted."278 The trial court denied Eskridge's application for a transcript and he filed in the Washington Supreme Court a motion for a writ of mandate ordering the trial judge to furnish a transcript. The Washington court denied the petition for a writ of mandate and dismissed Eskridge's appeal. Then Eskridge petitioned for a writ of habeas corpus; the petition was turned down by the Washington Supreme Court. The United States Supreme Court granted certiorari and the denial of the writ of habeas corpus was reversed in a per curiam opinion. In the Ross case, which had a procedural history substantially the same as that in Eskridge, the Supreme Court vacated the judgment and remanded for consideration in the light of Eskridge.

Retroactive application.-Both the Eskridge and Ross cases indicate that the Griffin doctrine will be applied to pre-Griffin convictions. ${ }^{279}$ Although both Eskridge and Ross made timely appeals and promptly requested transcripts, and so presented the strongest case for retroactive application of Griffin, still there is some basis for speculation that such application may be made in every case. Neither the Griffin nor the Eskridge opinions indicated that the former's

275357 U.S. 214 (1958).

275357 U.S. 575 (1958). The Ross case was decided with Woods v. Rhay. The facts of the latter case are unknown; no opinion on it seems to have been reported.

${ }^{277}$ Another question left open by the Griffin case was whether the doctrine of that decision would be extended to require the appointment of counsel as well as the order for a transcript. Ross did not ask for counsel, and the Court's disregard of Eskridge's request seems to indicate not an interpretation of Griffin, but rather a lack of merit in the request. Eskridge did not raise the issue of his right to counsel either before the state court or in his petition for certiorari. (Brief for Respondent at 33). Furthermore, he discharged his own attorney, did not ask the trial court to appoint a new one (Brief for Petitioner at 47), and indicated that he intended to prosecute his own appeal. (Transcript of Record at 69). Therefore, even though the Court has required the appointment of counsel in a group of recent cases involving appeals in the federal courts, see note 315 infra, the right of indigents to counsel in state appeals appears to be still unresolved.

278 Wash. Rev. Code (1957) \$ 2.32.240.

${ }^{279}$ Eskridge was convicted in 1935, Ross in 1950. 
doctrine was to have only prospective application; ${ }^{280}$ the significance of this omission is underscored by the denial of a petition for rehearing in Griffin requesting such an interpretation..$^{281}$ Moreover, any future attempt to distinguish Eskridge or Ross from a case in which no appeal or request for transcript was promptly made would undoubtedly have to rest on the contention that the prisoners, by failing to act, had knowingly waived their constitutional rights, ${ }^{282}$ a position which would be difficult to maintain.

Frivolous appeals.-Prior to the time Griffin was decided, the Illinois statute provided no opportunity for an indigent prisoner to obtain a free transcript. The Washington statute, on the other hand, included a discretionary provision under which the trial judge could order a free transcript to be prepared if in his opinion "justice will thereby be promoted." ${ }^{283}$ In holding the Washington statute violated the Griffin principle, the Court said in Eskridge that "[tlhe conclusion of the trial judge that there was no reversible error in the trial cannot be an adequate substitute for the right to full appellate review available to all defendants in Washington who can afford the expense of a transcript." ${ }^{284}$ This result seems to indicate that the interest of the state in minimizing waste of both time and expense in dealing with an indigent prisoner who has everything to gain and nothing to lose by prosecuting even the most frivolous appeal carries little weight. Such a view is perhaps not surprising in view of the Court's recent rejection of a similar discretionary device in the federal system. ${ }^{285}$ Moreover, the broad language which the Court used in invalidating the Washington provision indicates that no such devices, whether phrased in terms of "promoting justice," 286 "bad faith,"287 or "essential to the protection of substantial rights," ${ }^{288}$ will be found to meet the constitutional requirements.

Whether or not the rejection of the trial judge as an apt person to filter out frivolous appeals is a wise decision need not be debated here; some question may be raised, however, as to the rationale upon which the determination is made. Griffin hinted that the Court was concerned with closing the gap between the rich and poor defendant, and that state procedures were in some measure to be tested by the equality of treatment which they afforded. The language of Eskridge would support such an interpretation. Since equality between rich and poor is an ideal never to be attained at any stage of a criminal proceeding, it might be suggested that a fair procedure, rather than an equal procedure, is the goal to be pursued. Some of the difficulties which may be encountered in the search for equal treatment are indicated in the discussion below of the Ross case.

${ }^{280}$ The question of retroactivity was raised by Mr. Justice Frankfurter in his concurrence in Griffin v. Illinois, 351 U.S. 12, 25 (1955), and is the basis for the dissent of Justices Harlan and Whittaker in Eskridge.

281351 U.S. 958 (1955).

${ }^{282}$ See Walker v. Johnston, 312 U.S. 275, 286 (1940).

${ }^{283}$ Wash. Rev. Code (1957) $\$ 2.32 .240$.

284357 U.S. 214, 216 (1958).

285 See note 315 infra.

${ }^{286}$ Wash. Rev. Code (1957) § 2.32.240; Ore. Rev. Stat. (1955) §21.470.

${ }^{287} 62$ Stat. 1954 (1948), as amended, 28 U.S.C.A. \$ 1915 (1950).

${ }^{288}$ S.D. Code (1939) $\$ 34.3903$. 
Adequate review.-At one place in Griffin the Court declared that "destitute defendants must be afforded as adequate appellate review"289 as defendants with means. It was, however, not made clear whether the quoted phrase was intended to mean that indigents must be provide with the same aids to review or whether substantial equivalents would suffice. ${ }^{290}$ The problem was urged upon the Court in Eskridge where the defendant pointed out that even if an appeal could have been perfected without a transcript, the added burden borne by a prisoner without a transcript is so substantial as to override any argument that there can in fact be an equivalent of the stenographic record. ${ }^{291}$ The Court did not direct itself to this issue in Eskridge, ${ }^{292}$ but appears to have squarely faced it in the Ross case.

Ross was decided per curiam by the Washington Supreme Court ${ }^{293}$ solely on the authority of Grady v. Sckneckloth. ${ }^{294}$ The Grady case, after approving the discretionary Washington statute, held in addition that the statutes ${ }^{295}$ and cases $^{296}$ in Washington clearly showed that an appeal may be successfully prosecuted upon a narrative statement by the prisoner without the necessity of a stenographic transcript or statement of facts; the petitioner therefore ought to be required to carry through whatever procedure is available to him on his own before he asks anything of the state. The court in Grady thought that since such a procedure would provide adequate and effective review, there was no conflict with the Griffin doctrine.

In Grady, and thus in Ross, the Washington court denied the prisoner's peti-

289351 U.S. 12, 19 (1955). (Italics added.)

${ }^{290}$ See id., at 20.

291 Brief for Petitioner at 29-35.

${ }^{292}$ Although the state denied the allegation that a transcript was required, the Court said, "the Washington courts appear to have proceeded on the assumption that he could not effectively prosecute his appeal unless the motion for a free transcript was granted." 357 U.S. 214, 215-16 (1958). The Court also found that there was nothing to show that any other means was available. The basis of these assumptions appears to be the fact that when the Washington court denied the petition for a transcript, it simultaneously dismissed the appeal.

29351 Wash.2d 893, 318 P.2d 975 (1957).

${ }^{294} 51$ Wash.2d 1, 314 P.2d 930 (1957), cert. denied sub nom. Grady v. Rhay, 357 U.S. 939 (1958). Grady had filed a timely appeal and presented a narrative statement prepared by himself. He failed to serve it upon the prosecuting attorney and neglected to file it in the trial court as required by Washington law and the chief justice returned it, advising Grady of its inadequacy. But, rather than following through on the narrative statement, Grady abandoned it and applied for a statement of facts from the court under Wash. Rev. Code (1957) \$2.32.240. The request was denied and the state supreme court denied an application for habeas corpus. It is interesting to note that certiorari was denied in Grady on the same day that Ross was decided. One may speculate about why these two cases, which present precisely the same problem, should be treated differently. Grady's counsel has informed the Review that he was assured by the Washington court that Grady's case will be reconsidered after the Ross decision is handed down.

${ }_{225}$ Rule 34(3), 34A Wash.2d 36 (1951). Although Wash. Rev. Code (1957) § 2.32 .240 indicates that a transcript might be required, there is no inevitability that ic will and there appear to be few occasions, if any, on which it is compelled. See cases cited in note 296 infra.

${ }^{296}$ Palin v. General Construction Co., 45 Wash.2d 721, 277 P.2d 703 (1954); Livermore v. Northwest Airlines, 6 Wash.2d 1, 106 P.2d 578 (1940). 
tion on two grounds: (1) the discretionary Washington statute was valid and (2) the doctrine enunciated above requires the prisoner to file a narrative statement rather than ask for a free transcript. When the Washington court reconsiders the Ross case in the light of Eskridge, pursuant to the mandate of the Supreme Court, the conclusion must be reached that the first ground of the Grady-Ross decisions is erroneous in light of Griffin. However, a consideration of Eskridge will shed no light upon the validity of the second ground. ${ }^{297}$ Since it is clear that the Washington court considered its second ground sufficient by itself, and since Eskridge does not deal with the validity of that ground, it might be asked what the Court meant to accomplish by remanding the Ross case. If the Court agrees with the Washington court that the second ground accords with the requirements of Griffin, certiorari could merely have been denied in Ross. On the other hand, if the second ground could not constitutionally meet the Griffin requirement, the Court could have simply reversed.

Perhaps the best view is that Ross was remanded in order to give the Washington court a chance to clarify its position that, even though the first ground be discredited, the second ground still stands as an independent reason for denying free transcripts to indigent prisoners. If this view is correct, then the court's adjudication in Ross is tantamount to a holding that a state satisfies the constitutional requirements of Griffin by giving indigents some opportunity to get full appellate review, even though that opportunity may impose upon the indigent prisoner burdens not present for the affluent. It would then appear that Ross pours content into the concept of "as adequate appellate review" set forth in Grifin.

\section{DUE PROCESS AND SINGLE TRANSACTION-MULTIPLE OFFENSE CASES}

In Ciucci v. Illinois ${ }^{298}$ the petitioner was charged in four separate indictments with the murder of his wife and three children, all of whom were found in a razed building with bullet wounds in their heads. In three successive trials he was found guilty of the first degree murder of his wife, then of one child, and finally of a second child. Penalties of twenty years, forty-five years, and death, respectively, were fixed by the juries. The Illinois Supreme Court affirmed the death sentence ${ }^{299}$ and the United States Supreme Court granted certiorari to consider Ciucci's claim that, by bringing three separate trials under separate indictments and by obtaining repeated convictions upon the same evidence, the state sought merely to harass him until it achieved the desired capital verdict.

The precise question which Ciucci presented was whether due process is offended by successive trials for each offense occasioned by a single occurrence, when each offense rests upon precisely the same evidence and when each trial

${ }^{297}$ Both Eskridge and Griffin say that a stenographic transcript will not be required in every case, but Ross is the first case in which it has been necessary to adjudicate the validity of a substitute for a stenographic transcript.

${ }^{298} 356$ U.S. 571 (1958) (judgment affirmed with leave to the defendant to institute such further proceedings as may be available to substantiate his claim that unfavorable newspaper publicity denied him a fair trial).

${ }^{299} 8$ Ill.2d 619, 137 N.E.2d 40 (1956). 
is free from error. Although the Court had never before squarely faced this question, the conviction was affirmed in a brief opinion which cited only Palko ข. Connecticut ${ }^{300}$ and Hoag v. New Jersey ${ }^{301}$, the latter case decided the same day as Ciucci.

The Hoag case, like Ciucci, involved a single transaction which under the applicable state law constituted a multiplicity of offenses. ${ }^{302}$ The per curiam opinion in Ciucci cites those pages in Hoag where the Court expressed its reluctance to dictate inflexible rules to the states in their administration of the criminal law and stated that a procedure, however undesirable, will be invalidated only upon a showing that it is fundamentally unfair. Similarly, the Palko case probably was cited for its statement that state procedure will be voided only when it violates the "fundamental principles of liberty and justice which lie at the base of all our civil and political institutions." ${ }^{303}$ If this interpretation of the Ciucci decision is correct, the Court must have found that the Illinois procedure was not itself unconstitutional and that no fundamental unfairness had been proved by the defendant.

However, it should be noted that both Hoag and Palko differ from Ciucci in an important respect; in both of the former cases there was some taint in the initial trial ${ }^{304}$ and a second trial could be justified upon the principle that a state may constitutionally ask "no more than this, that the case against [the defendant] shall go on until there shall be a trial free from the corrosion of substantial legal error." 305 In Cincci successive trials were allowed though not to purge error and though no new evidence was introduced. It may reasonably be asked whether the Illinois procedure followed in Ciucci contains even that minimum degree of reasonableness which due process demands.

300302 U.S. 319 (1937).

301356 U.S. 464 (1958).

${ }^{302}$ Hoag allegedly had robbed five people during a tavern holdup. At the first trial, for the robberty of $A, B$, and $C$, the state called all five victims, each of whom had identified Hoag from police photographs; however, all of them except $\mathrm{E}$ failed to make a positive identification of Hoag in the courtroom. The prosecutor claimed surprise and attempted to impeach their testimony, but the jury nonetheless acquitted. The state then brought Hoag to trial for the robbery of $\mathrm{E}$, called only $\mathrm{E}$ as a witness, and obtained a conviction.

303302 U.S. at 328 (1937). For one view as to the application of the Palko test to multiple prosecutions, see Justice Brennan's special comments in Abbate v. United States, 359 U.S. 187, 196-201 (1959). Justice Black has expressed another view: "I think double prosecutions for the same offense are so contrary to the spirit of our free country that they violate even the prevailing view of the Fourteenth Amendment expressed in Palko v. Connecticut...." Bartkus v. Illinois, 359 U.S. 120, 150-51 (1959) (dissent). Justice Black also dissented in the Hoag and Ciucci cases.

${ }^{304}$ It should also be noted that in each of the cases cited as authority in the Hoag opinion some taint had infected the original trial. In Brock v. North Carolina, 344 U.S. 424 (1953), a mistrial was declared when two prosecution witnesses pleaded self-incrimination because judgments against them (they were partners in crime of the defendant but had been tried separately) had not yet been entered; the witnesses claimed they intended to appeal. In Wade v. Hunter, 336 U.S. 684 (1949), a court martial was dissolved when two vital prosecution witnesses were necessarily absent because of the exigencies of war; a second court martial was allowed. In Thompson v. United States, 155 U.S. 271 (1894), the jury was discharged when it was discovered that a juror had been a member of the grand jury; a second trial was permitted.

so6 Palko v. Connecticut, 302 U.S. 319, 328 (1937). 
Moreover, even if the unwillingness of the Court to invalidate the Illinois procedure can be understood, there remains the question of what means will be open to a defendant to indicate that he has been the victim of fundamentally unfair treatment. ${ }^{306}$ The Ciucci opinion gives no hint of the grounds on which such a showing might be made, but several possibilities may be suggested.

If harassment of the accused is the interest to be balanced against the state's desire for successive prosecutions, ${ }^{307}$ then the number of trials might be offered as a rule-of-thumb test of constitutionality. In the Graham case, ${ }^{308}$ for example where the accused allegedly planted a bomb on an airplane which exploded in mid-air killing forty-four people, it seems inconceivable that the Court would allow a state to subject the defendant to forty-four trials if that many were necessary to obtain a conviction or the desired penalty. Yet if, as Ciucci suggested in his brief, the potential harassment consists in the impoverishment of the defendant, the dissipation of favorable evidence by the passage of time, and the opportunity for the prosecution to improve its method of presentation, then the constitutional violation might occur as well at the second as at the fortyfourth trial. Thus, using the mere number of trials as a test of fundamental unfairness seems arbitrary and unrealistic.

It could also be argued that the crucial fact in the Ciucci case was not the number of trials, but rather the fact that each previous trial had resulted in a conviction and that the state was merely seeking what it thought was the proper penalty for each crime. ${ }^{309}$ Generalizing from this theory, it might be urged that one of the tests of constitutionality would be the order of verdicts. That is, an acquittal might put an end to the proceedings, but previous convictions, as in Ciucci, would permit the state to continue to prosecute in successive trials the other offenses charged. This view, however, presents several difficulties. In the Ciucci case, as would probably be true in most similar prosecutions, "all the gruesome details of the four crimes were presented to the jury" 310 at each trial and one might well wonder whether any of the juries in fact imposed a sentence merely for the particular crime charged. ${ }^{311}$ Second, if harassment and dissipation of resources is the core of potential unfairness, it is difficult to see why the fact that the defendant is fighting to determine the severity of his sentence rather than the issue of guilt or innocence makes a series of prosecu-

${ }^{306}$ The Court said in the Ciucci case that a second trial would not, in every case, be held constitutional, but would be invalidated if fundamental unfairness were shown. 356 U.S. 571, 573 (1958).

${ }^{307}$ Palko v. Connecticut, 302 U.S. 319, 328 (1937).

${ }^{308}$ Graham v. People, 134 Colo. 290, 302 P.2d 737 (1956).

${ }^{309}$ Brief for Respondent at 10.

${ }^{310}$ Justice Douglas dissenting in Ciucci, 356 U.S. 571, 574 (1958). In the cases in which a number of offenses spring from a single occurence the facts of each offense are usually so inextricably entwined that the state could hardly avoid bringing all of the facts into each trial. It should be noted that where different evidence is required to convict on each offense, separate considerations govern the claim that there may not be separate trials.

${ }^{311}$ See the newspaper accounts of statements of jurors which sat at the Ciucci trials. Brief for Petitioner at $47-52$. 
tions constitutionally justifiable. Finally, the view that an acquittal would put an end to trials, though it might serve to distinguish a case like Ciucci from one in which the first jury acquitted, may well produce a ludicrous result if, for example, acquittal were to come after one or several juries had convicted and imposed penalties which did not suit the prosecutor.

A further means by which unfairness might be demonstrated is by a plea of collateral estoppel; that is, the defendant might argue that since all issues have once been adjudicated, there should be an end to litigation. Such an argument was made in the Hoag case, but the Court there expressed "grave doubts" whether a plea of collateral estoppel would raise a constitutional issue. ${ }^{312}$ At any rate, the rather formalistic disposition of the argument in $\mathrm{Hoag}^{313}$ and the affirmance of a second trial in Bartkus v. Illinois s.4 $^{314}$ where an even more persuasive collateral estoppel claim was made, seem to indicate that this doctrine presents only the most limited possibilities for use by the victim of multiple prosecutions.

\section{J. Federal Criminat Law: 315 Search and Setzure by Federal Agents}

A question of the reasonableness of a search and seizure by federal agents was summarily disposed of in Joines $\%$. United States. ${ }^{316}$ The agents had acquired a warrant for Joines' arrest but had refrained from executing it for three weeks while they searched for the still they suspected Joines was operating. Unable to locate the still, the agents finally went to Joines' home to arrest him. His son told the officers he was not there, but they entered and searched the house without finding him. The agents then forced open a locked door to the cellar where they discovered the still, the evidence Joines tried to bar from the trial.

Joines argued that the officers had not lawfully been on the premises. The trial judge and the court of appeals held, however, that the officers discovered the still during a bona fide search for Joines. ${ }^{317}$ The Supreme Court vacated and

312356 U.S. 464,471 (1958).

${ }^{313}$ Id., at 472 . The Court said that the technical requirement of putting the victim in fear might have been met as to one victim but not as to another; thus the defendant could not successfully plead collateral estoppel.

${ }^{314}$ Aff'd by an equally divided Court, 355 U.S. 281 (1958); rehearing granted 356 U.S. 969 (1958); aff'd 359 U.S. 121 (1959), aff'g 7 Ill.2d. 138, 130 N.E.2d. 187 (1955). The petitioner, after being acquitted in a federal court for robbing a federally insured bank, was convicted in a state court for bank robbery.

315 Four of the 1957 term's per curiams deal with the right of an indigent federal prisoner to an appeal in forma pauperis. Ellis v. United States, 356 U.S. 674 (1958); Edwards v. United States, 355 U.S. 36 (1957); Hill v. United States, 356 U.S. 704 (1958); Cash v. United States, 357 U.S. 219 (1958). These cases are discussed fully in a comment which will appear in a subsequent issue of the Review.

316357 U.S. 573 (1958).

317 Agents may seize contraband materials which they find on premises which they have lawfully entered. See Smith v. United States, 2 F.2d 715 (C.A.4th, 1924); Federal Agent's Seizure of Contraband in Open View Following a Lawful Entry Not a Violation of Amendment IV of the United States Constitution, 4 N. Y. L. F. 439 (1958), noting United States v. McDaniel, 154 F.Supp. 1 (D.D.C., 1957). 
remanded the case to the court of appeals for reconsideration in the light of Jones $v$. United States, ${ }^{318}$ decided the same day as Joines.

In Jones federal agents, who had good reason to believe that the petitioner was operating an illegal still in his house, obtained a day-time search warrant but failed to execute it before darkness. Early in the evening, after they had been watching the house for several hours, the officers seized a quantity of illegal liquor from a truck leaving the yard. They then proceeded, over the objections of petitioner's wife, to search the house where they discovered the still. The petitioner was arrested when he returned to the house an hour after the search had been completed. The still was admitted in evidence over objection.

The court of appeals in Jones affirmed per curiam the finding of the trial court "that the facts and circumstances within the knowledge of the officers were sufficient ... to warrant . . a man of reasonable caution in the belief that an offense was being committed and therefore ... probable cause for the search existed at the time the search was made." ${ }_{119}$ The Supreme Court thought this finding was "not wholly free from ambiguity." ${ }^{220}$ The Court read the opinions below to say that the search was reasonable because the officers had probable cause to believe that inside the house were materials which were being used in the commission of a felony. So construed, the opinions below ran afoul of the long-established doctrine that a search without a warrant is not reasonable even though the searching officer believed that inside the building were objects which were subject to seizure. ${ }^{221}$ The Court refused to consider, saying it had not been properly presented, the government's contention that the agents had entered to arrest Jones and the search was incident to the intended arrest. Justices Burton and Clark dissented on the ground that the Court should construe doubtful findings to uphold the judgments below. ${ }^{322}$

It is not easy to determine why the Court thought Joines should be reconsidered in light of Jones. One clue may be found in the statement in Joines that Justices Burton and Clark dissented for the reasons stated in their dissent in Jones. ${ }^{323}$ From this it may be argued that the Court thought that the findings below in Joines could be construed to mean that the officers intended not an arrest but merely a search. However, the finding of the court of appeals was unambiguous:

${ }^{318} 357$ U.S. 493 (1958).

${ }^{319}$ Jones v. United States, 245 F.2d 32, 35 (C.A.5th, 1957).

${ }^{320} 357$ U.S. 493,497 (1958).

321 "Belief, however well founded, that an article sought is concealed in a dwelling house furnishes no justification for a search of that place without a warrant and such searches are held unlawful notwithstanding facts unquestionably showing probable cause." Agnello v. United States, 269 U.S. 20, 33 (1925). Accord: Temperani v. United States, 299 Fed. 365 (C.A.9th, 1924).

322357 U.S. 493, 502 (1958).

${ }^{323} 357$ U.S. 573 (1958). 
We are satisfied from the evidence, as was the trial judge, that the officers searched the defendant's house in a bona fide attempt to find and arrest him and that they did not know of the existence of the still therein until they came upon it in the course of their search for the defendant. ${ }^{324}$

Moreover, if the Supreme Court wanted to construe this finding like that in Jones, reversal, not a remand for reconsideration, was in order.

The difficulty of applying Jones to Joines plagued the court of appeals when it reconsidered the latter case. ${ }^{325}$ That court reaffirmed its prior judgment and pointed out that Joines was precisely the case which the Supreme Court expressly declined to consider in Jones, namely the situation where there was a search incident to a valid arrest. ${ }^{326}$

The remand is understandable if the Supreme Court decided that the arrest warrant, having been held for three weeks, was so stale that it was invalid. However, as pointed out by the court of appeals, there is little reason or precedent supporting such a holding. ${ }^{327}$ Perhaps the Supreme Court thought the arrest warrant was invalidated by the doctrine in $M c K$ night $v$. United States. ${ }^{328}$ That case held that an arrest warrant may not be held in abeyance and opportunities for arrest foregone in order that a search may be conveniently made in conjunction with an arrest. In Joines the agents claimed that they could not in good faith have obtained a search warrant because they did not believe the still was actually in the house. ${ }^{329}$ However, three weeks of searching had failed to produce the still; a search "incident to" Joines' arrest was an obvious method to determine if the still was in the house.

The lack of a reference to the $M c K n i g h t$ thesis indicates that in all likelihood the Court had something else in mind. But if that thesis was not relied on, there is no apparent reason why the arrest warrant and, consequently the search, were not valid. The bewilderment of the court of appeals over the remand thus appears to have been justified.

${ }^{324}$ Joines v. United States, 246 F.2d 278 (C.A.3d, 1957).

${ }^{325}$ Joines v. United States, 258 F.2d 471 (C.A.3d, 1957).

${ }^{326} \mathrm{Id}$., at $472-73$.

${ }^{327}$ Giordenello v. United States, 241 F.2d 575 (C.A.5th, 1957), rev'd on other grounds 357 U.S. 480 (1958); State v. Nadeau, 97 Me. 275, 54 Atl. 725 (1903). The staleness of a search vitiates the reasonableness of a search. For it is to be expected that the grounds on which a search warrant is issued will not be valid after a reasonable time has elapsed. See, e.g., State v. Miller, 329 Mo. 855, 46 S.W.2d 541 (1932). This analysis is inapplicable to arrest warrants. See, however, Olesen v. Pincock, 68 Utah 507, 251 Pac. 23 (1926).

${ }^{328} 183$ F.2d 977 (App.D.C., 1950).

${ }^{329}$ Brief in Opposition to the Petition for Writ of Certiorari at 6. 